\title{
THE REALITY OF STRATEGIC PLANNING
} FOR THE CENTRAL IRAQI FEDERATION BY HAND FROM THE POINT OF VIEW OF THE ADMINISTRATIVE BODIES OF THE CLUBS

\author{
Suheir Metab Manaf, Mona TalebThabet \\ University of Baghdad / College of Physical Education and Sports Sciences for Girls
}

DOI: $10.37648 / \mathrm{ijrssh} . v 10 \mathrm{i} 01.045$

Received:1 $8^{\text {th }}$ November 2019; Accepted:20 ${ }^{\text {th }}$ December, 2019; Published:17 $7^{\text {th }}$ January, 2020

\begin{abstract}
:
Sports management is the basis for sports institutions that work for the development of sports clubs because the latter is one of the main pillars of the sports institution as it has become the basis for the progress and development of peoples, and is the vibrant artery of that institution, through the proper use of capabilities and resources and material and human capabilities, as the One of the tasks of the administration is to employ those capabilities and resources positively and prepare individuals who are able to perform their administrative duties effectively so as to contribute to achieving the general goals of the institution in which they work and The sample was divided into (12) individuals for the survey sample, (120) individuals for the scale building sample, and (76) individuals for the sample application and The most important search results

Building and applying the strategic planning scale, which consisted of (82) paragraphs, was reached.
\end{abstract}

\section{INTRODUCTION}

Sports management is the basis for sports institutions that work for the development of sports clubs because the latter is one of the main pillars of the sports institution as it has become the basis for the progress and development of peoples, and is the vibrant artery of that institution, through the proper use of capabilities and resources and material and human capabilities, as the One of the tasks of the administration is to employ those capabilities and resources positively and prepare individuals who are able to perform their administrative duties effectively so as to contribute to achieving the general goals of the institution in which they work.

The strategic planning is important for the sports establishment to organize its work and improve its activities, according to a system that all employees participate in within a unified vision, and a documented message, which makes the outputs a sure guide, and an indicator of its most important indicators, and the planning process should start with the spread of culture and values, through the message The goals, ending with monitoring and evaluation, and that the union's work, whether internally or externally by organizing all administrative and technical matters entrusted to it, is only accomplished through setting a strategic plan in order to obtain the maximum amount of positive results that are the goal of clubs for competition, profit and To market and improve the level of performance in the best condition, as the 
importance of research lies in the strategic planning used by the Iraqi Federation by hand, and the practical methods used to improve planning.

Strategic planning, which is characterized by sound and solid standards for all its components, which is policy planning, systems, structure development, operations planning, investment of resources, development of human and material capabilities in order to achieve the goals of the Iraqi Federation by hand, and gives it the ability to conduct institutional organizational analysis, and update it regularly, with the aim of Achieving comprehensive institutional development within a framework of integrated performance flexibility aimed at continuous improvement and improvement.

The Iraqi Handball Federation, despite its experience and experience, and its continuous efforts to improve its performance, simulate its counterparts from other unions, and made efforts to develop strategic plans, seeking to improve its performance, and to provide practical contributions and models in change towards continuous improvement and effective performance.

Therefore, this research is a modest step towards building an administrative system that provides successful steps in strategic planning

The research aims: to build a scale of strategic planning. Knowing the reality of strategic planning for the Central Iraqi Federation by hand

Research imposition: The Central Iraqi Federation was distinguished by strategic planning.

\section{MATERIALS AND METHODS:}

The two researchers used the descriptive approach, using the survey method, and the research community was identified from the membership of the administrative bodies, who are (112) members of the first-level administrative body, and (96) members of the administrative body are an excellent degree. (100\%) of the research community. The sample was divided into (12) individuals for the survey sample, (120) individuals for the scale building sample, and (76) individuals for the sample application, as shown in Table (1).

Table (1)

Details of the research community, reconnaissance samples, construction and application

\begin{tabular}{|c|c|c|c|c|}
\hline $\begin{array}{l}\text { the total } \\
\text { number }\end{array}$ & percentage & Their number & Type of sample & sequence \\
\hline \multirow{4}{*}{208} & 5.50 & 12 & Survey Sample & 1 \\
\hline & 57.69 & 120 & Construction sample & 2 \\
\hline & 36.53 & 76 & Sample application & 4 \\
\hline & & 208 & Total sample & 5 \\
\hline
\end{tabular}

Means of gathering information, tools and devices used in research:

The researcher used the following tools, tools and devices

Arab and foreign sources -

Appendix interviews -

- Experts and specialists in the field of sports management, handball, Annex (1)

measurement and evaluation, Annex (2) -

.Field visits to collect information -

.- A special questionnaire for the purpose of determining the most important areas and paragraphs of the strategic planning scale, Annex (3) -

.Data collection and dump form -

.) - International Electronic Information Network (Internet

The assistant team work Annex (6) -

Dell electronic calculator.-

- Cas Casio stopwatch to know the time of answering the two scales paragraphs - while conducting the pilot experiment.

Field research procedures: 
Measurement procedure (strategic planning)

By examining the two researchers on previous studies and research, they found several measures that represent strategic planning, but when analyzing its paragraphs and axes, it does not fit the sample chosen for that, and they worked using some means to formulate paragraphs, fields that fit the sample of the research, and therefore the two researchers made several steps in order to obtain two metrics that are available. Scientific conditions, as the two researchers decided to merge the procedures for the two measures as the same procedures, and the most important steps that the two researchers followed in building the scale are: Determining the idea of the scale through reviewing previous studies and research, the researcher determined the idea of the scale B D that the two researchers define the idea of the scale, the goal of which was determined, which is to find a scientific way to get acquainted with the strategic planning of the Central Iraqi Union by hand from the point of view of administrative bodies, and after that the two researchers proposed and determined (10) fields for the scale of strategic planning and give a theoretical definition for each field and the two researchers were interested in giving The fields have a meaning for the studied phenomenon or the concept that is intended to be measured through the questionnaire Appendix (3), and it was presented to a number of experts and specialists in the field of sports management, handball, measurement, and calendar, and the number (29) is an appended expert (2), as they were asked to express their opinions in validity For fields and their definitions and the possibility of adding or merging any field they see fit and deleting or modifying inappropriate fields, according to the opinions of experts, the two researchers added the field of evaluation to strategic planning, and thus the number of scale fields has become (11), and they have adopted a value of (Ka) 2 to accept the areas of the scale, and below the level Indication (0.05) as shown in Tables (2).

Table (2)

The agreement of experts and specialists in the fields of strategic planning scale:

\begin{tabular}{|c|c|c|c|c|c|c|}
\hline Significant & $\begin{array}{l}\text { Significant } \\
\text { value }\end{array}$ & $\begin{array}{l}\text { Calculated } \\
\text { value of } \\
\text { (Ca) } 2\end{array}$ & Disagree & Okay & Candidate domains & sequence \\
\hline moral & 0.000 & 25.138 & 1 & 28 & Clarity of message & 1 \\
\hline moral & 0.000 & 29 & $\mathbf{0}$ & 29 & Clarity of vision & 2 \\
\hline moral & 0.000 & 29 & $\mathbf{0}$ & 29 & Objectives & 3 \\
\hline moral & 0.000 & 21.552 & 2 & 27 & Evaluating strategic plans & 4 \\
\hline moral & 0.000 & 21.552 & 2 & 27 & Control and follow-up & 5 \\
\hline moral & 0.000 & 29 & $\mathbf{0}$ & 29 & $\begin{array}{l}\text { Internal and external } \\
\text { environment analysis }\end{array}$ & 6 \\
\hline moral & 0.000 & 18.241 & 3 & 27 & $\begin{array}{l}\text { Information and } \\
\text { Communication Systems }\end{array}$ & 7 \\
\hline moral & 0.000 & 29 & $\mathbf{0}$ & 29 & Organizational Structure & 8 \\
\hline moral & 0.000 & 29 & $\mathbf{0}$ & 29 & $\begin{array}{l}\text { Financing and financial } \\
\text { management }\end{array}$ & 9 \\
\hline moral & 0.000 & 29 & $\mathbf{0}$ & 29 & Implement strategic plans & 10 \\
\hline moral & 0.000 & 18.241 & 3 & 27 & Calendar & 11 \\
\hline
\end{tabular}

Preparing paragraphs of the strategic planning scale

After the scale fields were identified for the two lists, the two researchers prepared a questionnaire for the fields and paragraphs of the scale annex (3), as the questionnaire contains selected paragraphs for the fields, provided that these paragraphs are distributed within the axes (fields), and each paragraph expresses the field in which it was placed and based on the theoretical definition The field in which the paragraph was placed with identifying alternatives to the proposed answer, as the number of paragraphs of the Strategic Planning Scale in the initial formula reached (133) paragraphs, and the two researchers used the method of selecting five alternatives (Likert), as a five-step scale was established (always, often, sometimes, rarely, Absolutely) and a ladder was arranged Starting degrees (5) Always (4) 
often (3) sometimes (2) rarely (never 1), and by the researcher taking into account the following aspects when formulating two measures:

.Each field should have its own paragraphs -

.That the paragraphs of each field express the theoretical definition of the field -

.Paragraph has only one specific meaning -

.Paragraphs have clear meaning and understandable words -

.Stay away from poorly understood paragraphs -

After that, the scale magazines were identified and the appropriate definition was set for each of them.

Determine the validity of the paragraphs:

The two researchers presented the scale to a group of (29) experts and specialists in a field in the field of sports management, handball, testing and measurement in the sports field for the purpose of looking at the paragraphs of the scale and the extent of their suitability and validity and to make observations and amend or delete the inappropriate paragraphs, and through a box such as any scale Strategic planning (103) out of (134) items, i.e. neglected (31) items distributed in (11) attached fields (4). The questionnaire for the scale of strategic planning in the initial image, and table (3) shows the value of the square of Kay for the two measures, knowing that the value of significance is Significant when it is $<0.05$

Table (3)

Validity of the paragraphs of the strategic planning scale

\begin{tabular}{|c|c|c|c|c|c|c|}
\hline Significant & $\begin{array}{l}\text { Significant } \\
\text { value }\end{array}$ & $\begin{array}{l}\text { Calculated } \\
\text { ka } 2\end{array}$ & Does not fit & Repair & Paragraphs & sequence \\
\hline moral & 0.000 & 29 & $\mathbf{0}$ & 29 & 1 & 1 \\
\hline moral & 0.000 & 29 & $\mathbf{0}$ & 29 & 2 & 2 \\
\hline moral & 0.000 & 15.207 & 4 & 25 & 3 & 3 \\
\hline moral & 0.000 & 15.207 & 4 & 25 & 4 & 4 \\
\hline moral & 0.000 & 29 & $\mathbf{0}$ & 29 & 5 & 5 \\
\hline moral & 0.000 & 29 & $\mathbf{0}$ & 29 & 6 & 6 \\
\hline moral & 0.041 & 4.172 & 9 & 20 & 7 & 7 \\
\hline moral & 0.000 & 29 & $\mathbf{0}$ & 29 & 8 & 8 \\
\hline moral & 0.000 & 29 & $\mathbf{0}$ & 29 & 9 & 9 \\
\hline غير معنوي & 0.853 & 0.034 & 15 & 14 & 10 & 10 \\
\hline moral & 0.000 & 15.207 & 4 & 25 & 11 & 11 \\
\hline moral & 0.000 & 12.448 & 5 & 24 & 12 & 12 \\
\hline moral & 0.000 & 18.241 & 3 & 26 & 13 & 13 \\
\hline moral & 0.041 & 4.172 & 9 & 20 & 14 & 14 \\
\hline moral & 0.000 & 29 & $\mathbf{0}$ & 29 & 15 & 15 \\
\hline moral & 0.002 & 9.966 & 6 & 23 & 16 & 16 \\
\hline moral & 0.005 & 7.759 & 7 & 22 & 17 & 17 \\
\hline Not moral & 0.149 & 1.690 & 11 & 18 & 18 & 18 \\
\hline moral & 0.000 & 25.138 & 1 & 28 & 19 & 19 \\
\hline
\end{tabular}




\begin{tabular}{|c|c|c|c|c|c|c|}
\hline moral & 0.000 & 18.241 & 3 & 26 & 20 & 20 \\
\hline moral & 0.000 & 18.241 & 3 & 26 & 21 & 21 \\
\hline Not moral & 0.149 & 1.690 & 11 & 18 & 22 & 22 \\
\hline Not moral & 0.853 & 0.034 & 15 & 14 & 23 & 23 \\
\hline moral & 0.000 & 21.552 & 2 & 27 & 24 & 24 \\
\hline moral & 0.000 & 15.207 & 4 & 25 & 25 & 25 \\
\hline moral & 0.000 & 15.207 & 4 & 25 & 26 & 26 \\
\hline moral & 0.000 & 18.241 & 3 & 26 & 27 & 27 \\
\hline moral & 0.000 & 18.241 & 3 & 26 & 28 & 28 \\
\hline moral & 0.041 & 4.172 & 9 & 20 & 29 & 29 \\
\hline moral & 0.000 & 18.241 & 3 & 26 & 30 & 30 \\
\hline moral & 0.041 & 4.172 & 9 & 20 & 31 & 31 \\
\hline moral & 0.000 & 21.552 & 2 & 27 & 32 & 32 \\
\hline moral & 0.000 & 21.552 & 2 & 27 & 33 & 33 \\
\hline Not moral & 0.353 & 0.862 & 12 & 17 & 34 & 34 \\
\hline moral & 0.002 & 9.966 & 6 & 23 & 35 & 35 \\
\hline moral & 0.005 & 7.759 & 7 & 22 & 36 & 36 \\
\hline moral & 0.000 & 21.552 & 2 & 27 & 37 & 37 \\
\hline Not moral & 0.353 & 0.862 & 12 & 17 & 38 & 38 \\
\hline moral & 0.000 & 21.552 & 2 & 27 & 39 & 39 \\
\hline Not moral & 0.353 & 0.862 & 12 & 17 & 40 & 40 \\
\hline moral & 0.002 & 9.966 & 6 & 23 & 41 & 41 \\
\hline Not moral & 0.353 & 0.862 & 12 & 17 & 42 & 42 \\
\hline moral & 0.002 & 9.966 & 6 & 23 & 43 & 43 \\
\hline moral & 0.002 & 9.966 & 6 & 23 & 44 & 44 \\
\hline moral & 0.002 & 9.966 & 6 & 23 & 45 & 45 \\
\hline Not moral & 0.353 & 0.862 & 12 & 17 & 46 & 46 \\
\hline moral & 0.005 & 7.759 & 7 & 22 & 47 & 47 \\
\hline moral & 0.005 & 7.759 & 7 & 22 & 48 & 48 \\
\hline moral & 0.000 & 21.552 & 2 & 27 & 49 & 49 \\
\hline moral & 0.041 & 4.172 & 9 & 20 & 50 & 50 \\
\hline moral & 0.016 & 5.828 & 8 & 21 & 51 & 51 \\
\hline moral & 0.002 & 9.966 & 6 & 23 & 52 & 52 \\
\hline moral & 0.002 & 9.966 & 6 & 23 & 53 & 53 \\
\hline Not moral & 0.577 & 0.310 & 13 & 16 & 54 & 54 \\
\hline moral & 0.041 & 4.172 & 9 & 20 & 55 & 55 \\
\hline Not moral & 0.577 & 0.310 & 13 & 16 & 56 & 56 \\
\hline moral & 0.041 & 4.172 & 9 & 20 & 57 & 57 \\
\hline
\end{tabular}




\begin{tabular}{|c|c|c|c|c|c|c|}
\hline moral & 0.041 & 4.172 & 9 & 20 & 58 & 58 \\
\hline Not moral & 0.149 & 1.690 & 11 & 18 & 59 & 59 \\
\hline moral & 0.002 & 9.966 & 6 & 23 & 60 & 60 \\
\hline moral & 0.000 & 21.552 & 2 & 27 & 61 & 61 \\
\hline moral & 0.041 & 4.172 & 9 & 20 & 62 & 62 \\
\hline moral & 0.016 & 5.828 & 8 & 21 & 63 & 63 \\
\hline moral & 0.002 & 9.966 & 6 & 23 & 64 & 64 \\
\hline moral & 0.002 & 9.966 & 6 & 23 & 65 & 65 \\
\hline Not moral & 0.577 & 0.310 & 13 & 16 & 66 & 66 \\
\hline moral & 0.000 & 21.552 & 2 & 27 & 67 & 67 \\
\hline Not moral & 0.577 & 0.310 & 13 & 16 & 68 & 68 \\
\hline moral & 0.000 & 21.552 & 2 & 27 & 69 & 69 \\
\hline moral & 0.002 & 9.966 & 6 & 23 & 70 & 70 \\
\hline moral & 0.000 & 21.552 & 2 & 27 & 71 & 71 \\
\hline moral & 0.041 & 4.172 & 9 & 20 & 72 & 72 \\
\hline moral & 0.041 & 4.172 & 9 & 20 & 73 & 73 \\
\hline moral & 0.000 & 21.552 & 2 & 27 & 74 & 74 \\
\hline moral & 0.000 & 21.552 & 2 & 27 & 75 & 75 \\
\hline moral & 0.000 & 15.207 & 4 & 25 & 76 & 76 \\
\hline moral & 0.000 & 15.207 & 4 & 25 & 77 & 77 \\
\hline Not moral & 0.577 & 0.310 & 13 & 16 & 78 & 78 \\
\hline Not moral & 0.577 & 0.310 & 13 & 16 & 79 & 79 \\
\hline moral & 0.000 & 15.207 & 4 & 25 & 80 & 80 \\
\hline moral & 0.000 & 15.207 & 4 & 25 & 81 & 81 \\
\hline Not moral & 0.149 & 1.690 & 11 & 18 & 82 & 82 \\
\hline Not moral & 0.149 & 1.690 & 11 & 18 & 83 & 83 \\
\hline moral & 0.000 & 21.552 & 2 & 27 & 84 & 84 \\
\hline moral & 0.041 & 4.172 & 9 & 20 & 85 & 85 \\
\hline moral & 0.000 & 21.552 & 2 & 27 & 86 & 86 \\
\hline moral & 0.005 & 7.759 & 7 & 22 & 87 & 87 \\
\hline moral & 0.000 & 21.552 & 2 & 27 & 88 & 88 \\
\hline moral & 0.000 & 15.207 & 4 & 25 & 89 & 89 \\
\hline moral & 0.000 & 15.207 & 4 & 25 & 90 & 90 \\
\hline moral & 0.000 & 25.138 & 1 & 28 & 91 & 91 \\
\hline moral & 0.000 & 25.138 & 1 & 28 & 92 & 92 \\
\hline Not moral & 0.149 & 1.690 & 11 & 18 & 93 & 93 \\
\hline moral & 0.000 & 25.138 & 1 & 28 & 94 & 94 \\
\hline moral & 0.005 & 7.759 & 7 & 22 & 95 & 95 \\
\hline
\end{tabular}




\begin{tabular}{|c|c|c|c|c|c|c|}
\hline moral & 0.005 & 7.759 & 7 & 22 & 96 & 96 \\
\hline moral & 0.000 & 21.552 & 2 & 27 & 97 & 97 \\
\hline moral & 0.000 & 25.138 & 1 & 28 & 98 & 98 \\
\hline moral & 0.000 & 25.138 & 1 & 28 & 99 & 99 \\
\hline Not moral & 0.577 & 0.310 & 13 & 16 & 100 & 100 \\
\hline moral & 0.000 & 25.138 & 1 & 28 & 101 & 101 \\
\hline moral & 0.000 & 25.138 & 1 & 28 & 102 & 102 \\
\hline Not moral & 0.577 & 0.310 & 13 & 16 & 103 & 103 \\
\hline moral & 0.002 & 9.966 & 6 & 23 & 104 & 104 \\
\hline moral & 0.002 & 9.966 & 6 & 23 & 105 & 105 \\
\hline Not moral & 0.353 & 0.862 & 12 & 17 & 106 & 106 \\
\hline moral & 0.002 & 9.966 & 6 & 23 & 107 & 107 \\
\hline moral & 0.000 & 25.138 & 1 & 28 & 108 & 108 \\
\hline moral & 0.002 & 9.966 & 6 & 23 & 109 & 109 \\
\hline moral & 0.002 & 9.966 & 6 & 23 & 110 & 110 \\
\hline Not moral & 0.353 & 0.862 & 12 & 17 & 111 & 111 \\
\hline moral & 0.000 & 25.138 & 1 & 28 & 112 & 112 \\
\hline Not moral & 0.853 & 0.034 & 15 & 14 & 113 & 113 \\
\hline Not moral & $\mathbf{0 . 5 7 7}$ & 0.310 & 13 & 16 & 114 & 114 \\
\hline moral & 0.041 & 4.172 & 9 & 20 & 115 & 115 \\
\hline moral & 0.000 & 25.138 & 1 & 28 & 116 & 116 \\
\hline moral & 0.041 & 4.172 & 9 & 20 & 117 & 117 \\
\hline moral & 0.000 & 21.552 & 2 & 27 & 118 & 118 \\
\hline Not moral & 0.149 & 1.690 & 11 & 18 & 119 & 119 \\
\hline moral & 0.041 & 4.172 & 9 & 20 & 120 & 120 \\
\hline Not moral & 0.853 & 0.034 & 15 & 14 & 121 & 121 \\
\hline moral & 0.000 & 25.138 & 1 & 28 & 122 & 122 \\
\hline moral & 0.000 & 25.138 & 1 & 28 & 123 & 123 \\
\hline Not moral & 0.577 & 0.310 & 13 & 16 & 124 & 124 \\
\hline moral & 0.000 & 21.552 & 2 & 27 & 125 & 125 \\
\hline moral & 0.000 & 21.552 & 2 & 27 & 126 & 126 \\
\hline Not moral & 0.149 & 1.690 & 11 & 18 & 127 & 127 \\
\hline moral & 0.041 & 4.172 & 9 & 20 & 128 & 128 \\
\hline moral & 0.000 & 15.207 & 4 & 25 & 129 & 129 \\
\hline moral & 0.000 & 25.138 & 1 & 28 & 130 & 130 \\
\hline moral & 0.000 & 15.207 & 4 & 25 & 131 & 131 \\
\hline moral & 0.041 & 4.172 & 9 & 20 & 132 & 132 \\
\hline Not moral & 0.853 & 0.034 & 15 & 14 & 133 & 133 \\
\hline
\end{tabular}




\begin{tabular}{|l|l|l|l|l|l|l|}
\hline Not moral & 0.353 & 0.862 & 12 & 17 & 134 & 134 \\
\hline
\end{tabular}

\section{Exploratory experience:}

The two researchers applied the exploratory experiment to a group of 12 members of the administrative bodies in the handball game on Thursday 8/8/2019 at their workplace. The sample acceptance of the scale was revealed through clarity of instructions and ease of understanding and clarity of the paragraphs, and the two researchers did not face Or the auxiliary team, any negatives or constraints.

Applying the two strategic planning criteria to the construction sample:

After the fields and paragraphs were tested by the experts, it became prepared for application. Appendix (4), which was applied with the help of the auxiliary work team on the construction sample of (120) members of the administrative bodies and for the period from Wednesday 14/8/2019 until Tuesday 8/27/ 2019, and after completing the implementation of the main experiment, the two researchers arranged the scale questionnaires, corrected them, and recorded the results in preparation for statistical analysis. Some descriptive statistics were found on the sample and table (4) shows that.

Table (4)

Shows the descriptive characteristics of the strategic planning scale

\begin{tabular}{|l|l|}
\hline Strategic Planning & Properties \\
\hline $\mathbf{3 5 0 . 8 8 3 3}$ & the middle \\
\hline $\mathbf{3 5 0 . 5 0 0 0}$ & standard deviation \\
\hline $\mathbf{3 6 3 . 0 0}$ & skewness \\
\hline $\mathbf{1 5 . 6 1 6 2 9}$ & Standard error \\
\hline $\mathbf{- 0 . 1 1 3 -}$ & The lowest degree \\
\hline $\mathbf{3 0 7 . 0 0}$ & The highest degree \\
\hline
\end{tabular}

The psychometric properties of the two strategic planning criteria:

The psychometric properties of the scale include the ability of the scale to be prepared for its measurement, and it also includes the ability of the scale to measure the phenomenon with an acceptable degree of accuracy or with minimal errors (Odeh, 1998, page 335)

Validate the scale:

Honesty is for the test to measure the ability, attribute, or willingness that the test was developed to measure, that is, to actually measure what it is intended to measure (Radwan M., 2009, page 255), as the researcher relied on several types of honesty to verify the validity of the two measures.

Certify the content

The two researchers achieved this kind by rational analysis of the content of the scale and determining it based on subjective judgments. There are two types of honesty, which are apparent honesty and in-kind honesty.

Virtual validity

This type of honesty has been achieved and the scale paragraphs have been determined using the help of a group of sports management experts, tests and the attached measurement (2), and each arbitrator has been asked to determine the validity of each phrase (valid, not valid) and the appropriateness of the amendment of the paragraphs in proportion to the sample used as explained above.

Paragraph Discriminative Ability:

To verify the discriminatory power of the vertebrae whose vertebrae are leading, the value of (T) must be a function between the upper and lower group results of the statistical analysis sample for each of the vertebrae (Hussein K., 2008, page 100).

Thus, the grades of each paragraph were arranged in ascending order from the lowest to the highest degree (27\%) were chosen from the lower grades and the same are from the higher grades, and the $27 \%$ of the upper group and $27 \%$ of the lower group are the best percentage by which we obtain the highest discrimination factors. After statistically treating the 
results, it became clear that the paragraphs are valid, because the values of (Sig) are smaller than the significance level of (0.05) and as in Table (5)

Table (5): Shows the discriminatory ability of each paragraph of the Strategic Planning scale

\begin{tabular}{|c|c|c|c|c|c|c|c|}
\hline \multirow{2}{*}{$\begin{array}{l}\text { The } \\
\text { result }\end{array}$} & \multirow{2}{*}{$\begin{array}{l}\text { Signific } \\
\text { ant } \\
\text { value }\end{array}$} & \multirow{2}{*}{$\begin{array}{l}\text { Calculated } \\
\text { value }(\mathrm{t})\end{array}$} & \multicolumn{2}{|c|}{ Upper group } & \multicolumn{2}{|c|}{ Lower group } & \multirow{2}{*}{$\begin{array}{l}\text { Paragraph } \\
\text { number }\end{array}$} \\
\hline & & & $\begin{array}{l}\text { standard } \\
\text { deviation }\end{array}$ & $\begin{array}{l}\text { Arithmetic } \\
\text { mean }\end{array}$ & $\begin{array}{l}\text { standard } \\
\text { deviation }\end{array}$ & $\begin{array}{l}\text { Arithmetic } \\
\text { mean }\end{array}$ & \\
\hline moral & 0.000 & 70.855 & .00000 & 5.0000 & .37134 & 2.1628 & 1 \\
\hline moral & 0.000 & 73.323 & .00000 & 5.0000 & .36031 & 2.1512 & 2 \\
\hline moral & 0.000 & 76.109 & .00000 & 5.0000 & .34854 & 2.1395 & 3 \\
\hline moral & 0.000 & 71.110 & .18456 & 4.9651 & .32244 & 2.1163 & 4 \\
\hline moral & 0.000 & 55.927 & .00000 & 5.0000 & .45117 & 2.2791 & 5 \\
\hline moral & 0.000 & $\mathbf{5 5 . 9 2 7}$ & .00000 & 5.0000 & .45117 & 2.2791 & 6 \\
\hline moral & 0.000 & 70.855 & .00000 & 5.0000 & .37134 & 2.1628 & 7 \\
\hline moral & 0.000 & 60.395 & .42494 & 4.7674 & .00000 & 2.0000 & 8 \\
\hline moral & 0.000 & 48.349 & .41731 & 4.7791 & .49415 & 1.4070 & 9 \\
\hline moral & 0.000 & 47.916 & .39143 & 4.8140 & .50239 & 1.5233 & 10 \\
\hline moral & 0.000 & 44.233 & .46682 & 4.6860 & .49801 & 1.4302 & 11 \\
\hline moral & 0.000 & 40.944 & .15160 & 4.9767 & .65966 & 1.9884 & 12 \\
\hline moral & 0.000 & 52.124 & .47134 & 4.6744 & .40058 & 1.1977 & 13 \\
\hline moral & 0.000 & 44.485 & .00000 & 5.0000 & .62298 & 2.0116 & 14 \\
\hline moral & 0.000 & 48.182 & .38169 & 4.8256 & .47134 & 1.6744 & 15 \\
\hline moral & 0.000 & 114.225 & .15160 & 4.9767 & .18456 & 2.0349 & 16 \\
\hline moral & 0.000 & 61.072 & .21183 & 4.9535 & .43888 & 1.7442 & 17 \\
\hline moral & 0.000 & 65.226 & .15160 & 4.9767 & .43212 & 1.7558 & 18 \\
\hline moral & 0.000 & 53.682 & .29217 & 4.9070 & .48295 & 1.6395 & 19 \\
\hline moral & 0.000 & 43.047 & .50239 & 4.5233 & .47134 & 1.3256 & 20 \\
\hline moral & 0.000 & 47.428 & .47553 & 4.6628 & .45675 & 1.2907 & 21 \\
\hline moral & 0.000 & 46.953 & .48914 & 4.6163 & .44522 & 1.2674 & 22 \\
\hline moral & 0.000 & 96.337 & .21183 & 4.9535 & .18456 & 2.0349 & 23 \\
\hline
\end{tabular}




\begin{tabular}{|c|c|c|c|c|c|c|c|}
\hline moral & 0.000 & 60.133 & .23538 & 4.9419 & .36031 & 2.1512 & 24 \\
\hline moral & 0.000 & 49.340 & .43212 & 4.7558 & .47553 & 1.3372 & 25 \\
\hline moral & 0.000 & 50.526 & .45117 & 4.7209 & .44522 & 1.2674 & 26 \\
\hline moral & 0.000 & 45.412 & .45117 & 4.7209 & .49801 & 1.4302 & 27 \\
\hline moral & 0.000 & 44.242 & .47940 & 4.6512 & .48914 & 1.3837 & 28 \\
\hline moral & 0.000 & 41.192 & .49415 & 4.5930 & .50171 & 1.4651 & 29 \\
\hline moral & 0.000 & 43.275 & .45675 & 4.7093 & .50075 & 1.5465 & 30 \\
\hline moral & 0.000 & 50.175 & .37134 & 4.8372 & .33595 & 2.1279 & 31 \\
\hline moral & 0.000 & 67.704 & .25625 & 4.9302 & .29217 & 2.0930 & 32 \\
\hline moral & 0.000 & 65.413 & .30790 & 4.8953 & .25625 & 2.0698 & 33 \\
\hline moral & 0.000 & 49.516 & .40058 & 4.8023 & .30790 & 2.1047 & 34 \\
\hline moral & 0.000 & 92.269 & .00000 & 5.0000 & .29217 & 2.0930 & 35 \\
\hline moral & 0.000 & 37.669 & .44522 & 4.7326 & .42494 & 2.2326 & 36 \\
\hline moral & 0.000 & 52.348 & .34854 & 4.8605 & .33595 & 2.1279 & 37 \\
\hline moral & 0.000 & 55.953 & .23538 & 4.9419 & .39143 & 2.1860 & 38 \\
\hline moral & 0.000 & 39.661 & .37134 & 4.8372 & .46196 & 2.3023 & 39 \\
\hline moral & 0.000 & 45.020 & .34854 & 4.8605 & .41731 & 2.2209 & 40 \\
\hline moral & 0.000 & 61.791 & .34854 & 4.8605 & .23538 & 2.0581 & 41 \\
\hline moral & 0.000 & 68.650 & .00000 & 5.0000 & .38169 & 2.1744 & 42 \\
\hline moral & 0.000 & 82.938 & .32244 & 4.8837 & .00000 & 2.0000 & 43 \\
\hline moral & 0.000 & 56.618 & .36031 & 4.8488 & .27505 & 2.0814 & 44 \\
\hline moral & 0.000 & 82.938 & .32244 & 4.8837 & .00000 & 2.0000 & 45 \\
\hline moral & 0.000 & 77.072 & .29217 & 4.9070 & .18456 & 2.0349 & 46 \\
\hline moral & 0.000 & 104.111 & .18456 & 4.9651 & .18456 & 2.0349 & 47 \\
\hline moral & 0.000 & 61.226 & .29217 & 4.9070 & .30790 & 2.1047 & 48 \\
\hline moral & 0.000 & 65.638 & .32244 & 4.8837 & .23538 & 2.0581 & 49 \\
\hline moral & 0.000 & 55.093 & .29217 & 4.9070 & .36031 & 2.1512 & 50 \\
\hline
\end{tabular}




\begin{tabular}{|c|c|c|c|c|c|c|c|}
\hline moral & 0.000 & 56.932 & .18456 & 4.9651 & .40920 & 2.2093 & 51 \\
\hline moral & 0.000 & 54.395 & .25625 & 4.9302 & .39143 & 2.1860 & 52 \\
\hline moral & 0.000 & 115.905 & .23538 & 4.9419 & .00000 & 2.0000 & 53 \\
\hline moral & 0.000 & 78.339 & .32244 & 4.8837 & .10783 & 2.0116 & 54 \\
\hline moral & 0.000 & 43.358 & .40920 & 4.7907 & .38169 & 2.1744 & 55 \\
\hline moral & 0.000 & 60.133 & .23538 & 4.9419 & .36031 & 2.1512 & 56 \\
\hline moral & 0.000 & 51.308 & .32244 & 4.8837 & .37134 & 2.1628 & 57 \\
\hline moral & 0.000 & 87.205 & .00000 & 5.0000 & .30790 & 2.1047 & 58 \\
\hline moral & 0.000 & 66.668 & .00000 & 5.0000 & .39143 & 2.1860 & 59 \\
\hline moral & 0.000 & 76.548 & .23538 & 4.9419 & .25625 & 2.0698 & 60 \\
\hline moral & 0.000 & 65.302 & .29217 & 4.9070 & .27505 & 2.0814 & 61 \\
\hline moral & 0.000 & 51.454 & .38169 & 4.8256 & .30790 & 2.1047 & 62 \\
\hline moral & 0.000 & 45.632 & .40058 & 4.8023 & .36031 & 2.1512 & 63 \\
\hline moral & 0.000 & 47.251 & .36031 & 4.8488 & .38169 & 2.1744 & 64 \\
\hline moral & 0.000 & 114.777 & .21183 & 4.9535 & .10783 & 2.0116 & 65 \\
\hline moral & 0.000 & 73.323 & .36031 & 4.8488 & .00000 & 2.0000 & 66 \\
\hline moral & 0.000 & 68.650 & .00000 & 5.0000 & .38169 & 2.1744 & 67 \\
\hline moral & 0.000 & 65.061 & .37134 & 4.8372 & .15160 & 2.0233 & 68 \\
\hline moral & 0.000 & 52.263 & .40920 & 4.7907 & .25625 & 2.0698 & 69 \\
\hline moral & 0.000 & 46.614 & .23538 & 4.9419 & .46682 & 2.3140 & 70 \\
\hline moral & 0.000 & 55.009 & .00000 & 5.0000 & .45675 & 2.2907 & 71 \\
\hline moral & 0.000 & 55.304 & .27505 & 4.9186 & .37134 & 2.1628 & 72 \\
\hline moral & 0.000 & 68.650 & .00000 & 5.0000 & .38169 & 2.1744 & 73 \\
\hline moral & 0.000 & 96.337 & .18456 & 4.9651 & .21183 & 2.0465 & 74 \\
\hline moral & 0.000 & 47.439 & .00000 & 5.0000 & .34854 & 2.1395 & 75 \\
\hline moral & 0.000 & 70.855 & .33595 & 4.8721 & .40058 & 2.1977 & 76 \\
\hline moral & 0.000 & 70.855 & .00000 & 5.0000 & .37134 & 2.1628 & 77 \\
\hline
\end{tabular}




\begin{tabular}{|c|c|c|c|c|c|c|c|}
\hline moral & 0.000 & 50.451 & .00000 & 5.0000 & .37134 & 2.1628 & 78 \\
\hline moral & 0.000 & 52.970 & .30790 & 4.8953 & .39143 & 2.1860 & 79 \\
\hline moral & 0.000 & 91.251 & .27505 & 4.9186 & .39143 & 2.1860 & 80 \\
\hline moral & 0.000 & 55.304 & .10783 & 4.9884 & .27505 & 2.0814 & 81 \\
\hline moral & 0.000 & 61.226 & .37134 & 4.8372 & .27505 & 2.0814 & 82 \\
\hline moral & 0.000 & 76.109 & .29217 & 4.9070 & .30790 & 2.1047 & 83 \\
\hline moral & 0.000 & 54.001 & .00000 & 5.0000 & .34854 & 2.1395 & 84 \\
\hline moral & 0.000 & 61.302 & .43212 & 4.7558 & .21183 & 1.9535 & 85 \\
\hline moral & 0.000 & 48.600 & .25625 & 4.9302 & .35955 & 2.0116 & 86 \\
\hline moral & 0.000 & 67.849 & .37134 & 4.8372 & .39090 & 2.0116 & 87 \\
\hline moral & 0.000 & 65.062 & .27505 & 4.9186 & .28673 & 2.0116 & 88 \\
\hline moral & 0.000 & 50.684 & .25625 & 4.9302 & .32350 & 2.0349 & 89 \\
\hline moral & 0.000 & 45.011 & .48295 & 4.6395 & .00000 & 2.0000 & 90 \\
\hline moral & 0.000 & 74.082 & .40920 & 4.7907 & .38668 & 2.0581 & 91 \\
\hline moral & 0.000 & 98.406 & .00000 & 5.0000 & .36390 & 2.0930 & 92 \\
\hline moral & 0.000 & 93.733 & .00000 & 5.0000 & .27505 & 2.0814 & 93 \\
\hline moral & 0.000 & 44.202 & .18456 & 4.9651 & .23538 & 1.9419 & 94 \\
\hline moral & 0.000 & 72.851 & .32244 & 4.8837 & .48578 & 2.1047 & 95 \\
\hline moral & 0.000 & 55.891 & .32244 & 4.8837 & .18456 & 1.9651 & 96 \\
\hline moral & 0.000 & 63.633 & .29217 & 4.9070 & .36912 & 2.0698 & 97 \\
\hline moral & 0.000 & 55.230 & .29217 & 4.9070 & .30679 & 2.0000 & 98 \\
\hline moral & 0.000 & 76.109 & .40920 & 4.7907 & .21183 & 2.0465 & 99 \\
\hline moral & 0.000 & 55.230 & .34854 & 4.8605 & .00000 & 2.0000 & 100 \\
\hline moral & 0.000 & 82.938 & .40920 & 4.7907 & .21183 & 2.0465 & 101 \\
\hline moral & 0.000 & 84.792 & .00000 & 5.0000 & .32244 & 2.1163 & 102 \\
\hline moral & 0.000 & 56.430 & .23538 & 4.9419 & .21183 & 2.0465 & 103 \\
\hline
\end{tabular}

The value of the significance is significant if it is $<0.05$ degrees of freedom (62) 
It is clear from Table (5) that all the strategic planning paragraphs have the ability to distinguish between the upper and lower levels, so no paragraph of the scale has been deleted.

The internal consistency of the strategic planning scale

The two researchers calculated the internal consistency of the scale by extracting the Pearson correlation coefficient between the degree of each phrase of the two measures and the total degree of the two measures on the construction sample, which amounted to (120) members of an administrative body and Table (6) shows the internal consistency of the scale of strategic planning.

Table (6): The correlation coefficient shows the degree of the paragraph and the overall degree of the strategic planning scale

\begin{tabular}{|c|c|c|c|c|c|c|c|}
\hline $\begin{array}{l}\text { The } \\
\text { result }\end{array}$ & $\begin{array}{l}\text { Significant } \\
\text { value }\end{array}$ & $\begin{array}{l}\text { Simple } \\
\text { correlation } \\
\text { coefficient }\end{array}$ & $\begin{array}{l}\text { Paragraph } \\
\text { number }\end{array}$ & The result & $\begin{array}{l}\text { Significant } \\
\text { value }\end{array}$ & $\begin{array}{l}\text { Simple } \\
\text { correlation } \\
\text { coefficient }\end{array}$ & $\begin{array}{l}\text { Paragraph } \\
\text { number }\end{array}$ \\
\hline moral & 0.000 & $0.229 * *$ & 54 & moral & 0.000 & $0.525 * *$ & 1 \\
\hline $\begin{array}{l}\text { Not } \\
\text { moral }\end{array}$ & 0.328 & 0.085 & 55 & moral & 0.000 & $0.238 * *$ & 2 \\
\hline moral & 0.029 & $0.222 *$ & 56 & moral & 0.000 & $0.310 * *$ & 3 \\
\hline moral & 0.001 & $0.184 * *$ & 57 & moral & 0.000 & $0.355 * *$ & 4 \\
\hline moral & 0.012 & $0.241 *$ & 58 & moral & 0.000 & $0.349 * *$ & 5 \\
\hline moral & 0.000 & $0.225 * *$ & 59 & moral & 0.007 & $0.251 * *$ & 6 \\
\hline moral & 0.000 & $0.149 * *$ & 60 & moral & 0.000 & $0.352 * *$ & 7 \\
\hline moral & 0.000 & $0.151 * *$ & 61 & moral & 0.000 & $0.321 * *$ & 8 \\
\hline $\begin{array}{l}\text { Not } \\
\text { moral }\end{array}$ & 0.359 & 0.092 & 62 & moral & 0.001 & $0.197 * *$ & 9 \\
\hline moral & 0.000 & $0.321 * *$ & 63 & moral & 0.000 & $0.365 * *$ & 10 \\
\hline $\begin{array}{l}\text { Not } \\
\text { moral }\end{array}$ & 0.475 & $-0.060-$ & 64 & moral & 0.000 & $0.278 * *$ & 11 \\
\hline $\begin{array}{l}\text { Not } \\
\text { moral }\end{array}$ & 0.655 & $-0.065-$ & 65 & moral & 0.000 & $0.382 * *$ & 12 \\
\hline moral & 0.000 & $0.234 * *$ & 66 & moral & 0.001 & $0.181 * *$ & 13 \\
\hline moral & 0.000 & $0.385 * *$ & 67 & moral & 0.000 & $0.240 * *$ & 14 \\
\hline moral & 0.007 & $0.171 * *$ & 68 & Not moral & 0.22 & 0.069 & 15 \\
\hline moral & 0.000 & $0.366 * *$ & 69 & Not moral & 0.27 & 0.099 & 16 \\
\hline moral & 0.000 & $0.288 * *$ & 70 & moral & 0.000 & $0.376 * *$ & 17 \\
\hline moral & 0.001 & $0.267 * *$ & 71 & moral & 0.000 & $0.343^{* *}$ & 18 \\
\hline moral & 0.000 & $0.445 * *$ & 72 & moral & 0.000 & $0.549 * *$ & 19 \\
\hline $\begin{array}{l}\text { Not } \\
\text { moral }\end{array}$ & .9810 & $-0.061-$ & 73 & moral & 0.000 & $0.267 * *$ & 20 \\
\hline $\begin{array}{l}\text { Not } \\
\text { moral }\end{array}$ & .2880 & .0900 & 74 & moral & 0.000 & $0.334 * *$ & 21 \\
\hline moral & 0.027 & 0.199* & 75 & moral & 0.000 & $0.385 * *$ & 22 \\
\hline
\end{tabular}




\begin{tabular}{|c|c|c|c|c|c|c|c|}
\hline moral & 0.030 & $0.177 *$ & 76 & Not moral & 0.202 & 0.072 & 23 \\
\hline moral & 0.034 & 0.118* & 77 & moral & 0.000 & $0.344 * *$ & 24 \\
\hline moral & 0.017 & $0.198 * *$ & 78 & moral & 0.000 & $0.263 * *$ & 25 \\
\hline $\begin{array}{l}\text { Not } \\
\text { moral }\end{array}$ & 0.926 & 0.005 & 79 & moral & 0.000 & $0.550 * *$ & 26 \\
\hline moral & 0.000 & $0.422 *$ & 80 & Not moral & 0.330 & 0.029 & 27 \\
\hline moral & 0.001 & $0.319 *$ & 81 & moral & 0.000 & $0.258 * *$ & 28 \\
\hline $\begin{array}{l}\text { Not } \\
\text { moral }\end{array}$ & 0.790 & 0.015 & 82 & moral & 0.000 & $0.287 * *$ & 29 \\
\hline moral & 0.000 & $* * 0.457$ & 83 & moral & 0.000 & $0.220 * *$ & 30 \\
\hline moral & 0.000 & $* * 0.521$ & 84 & Not moral & 0.388 & 0.049 & 31 \\
\hline $\begin{array}{l}\text { Not } \\
\text { moral }\end{array}$ & 0.422 & $-.045-$ & 85 & moral & 0.000 & $0.430 * *$ & 32 \\
\hline moral & 0.000 & $* * \mathbf{0 . 5 5 7}$ & 86 & moral & 0.000 & $0.334 * *$ & 33 \\
\hline moral & 0.000 & $* * \mathbf{0 . 7 3 9}$ & 87 & moral & 0.000 & $0.360 * *$ & 34 \\
\hline moral & 0.000 & $* * 0.618$ & 88 & Not moral & 0.311 & 0.029 & 35 \\
\hline $\begin{array}{l}\text { Not } \\
\text { moral }\end{array}$ & 0.177 & 0.076 & 89 & moral & 0.000 & $0.529 * *$ & 36 \\
\hline moral & 0.000 & $* * 0.713$ & 90 & moral & 0.000 & $0.258 * *$ & 37 \\
\hline moral & 0.000 & $0.675 * *$ & 91 & moral & 0.000 & $0.431 * *$ & 38 \\
\hline moral & 0.000 & $0.611 * *$ & 92 & moral & 0.000 & $0.430 * *$ & 39 \\
\hline moral & 0.031 & $0.121 *$ & 93 & moral & 0.000 & $0.353 * *$ & 40 \\
\hline moral & 0.021 & $0.112 *$ & 94 & Not moral & 0.601 & 0.088 & 41 \\
\hline $\begin{array}{l}\text { Not } \\
\text { moral }\end{array}$ & 0.077 & 0.099 & 95 & moral & 0.000 & $0.298 * *$ & 42 \\
\hline moral & 0.000 & $* * 0.486$ & 96 & moral & 0.000 & $0.181 * *$ & 43 \\
\hline moral & 0.000 & $* * 0.442$ & 97 & moral & 0.000 & $0.299 * *$ & 44 \\
\hline $\begin{array}{l}\text { Not } \\
\text { moral }\end{array}$ & 0.261 & 0.063 & 98 & Not moral & 0.176 & 0.076 & 45 \\
\hline moral & 0.000 & $* * 0.294$ & 99 & moral & 0.000 & $0.446^{* *}$ & 46 \\
\hline moral & 0.000 & $* * 0.444$ & 100 & moral & 0.002 & 0.299** & 47 \\
\hline moral & 0.000 & $* * 0.505$ & 101 & Not moral & 0.110 & 0.106 & 48 \\
\hline moral & 0.000 & **0.374 & 102 & moral & 0.000 & $\mathrm{0.433}^{* *}$ & 49 \\
\hline \multirow[t]{4}{*}{ moral } & 0.000 & $* * 0.621$ & 103 & moral & 0.000 & $0.430 * *$ & 50 \\
\hline & & & & Not moral & 0.913 & 0.006 & 51 \\
\hline & & & & moral & 0.001 & $0.338 * *$ & 52 \\
\hline & & & & moral & 0.000 & $0.221 * *$ & 53 \\
\hline
\end{tabular}

Significant at $<0.05$ and freedom degree N $-1=118$ 
From the previous table, it is clear to us that the number of paragraphs of the scale (103) items shows that all paragraphs are statistically significant except for paragraphs $(16,15,23,27,31,35,45,48,51,55,62,64,65,73,74,79,82,85,89,98,95)$ The two researchers excluded these paragraphs from the scale to make the scale (82) all of them significant.

Stability of scale: The two researchers extracted stability in three ways:

Midway segmentation method: This method measures the internal homogeneity of the scale paragraphs, as this homogeneity indicates the consistency of performance and stability when answering all the paragraphs, as this method is based on calculating the correlation coefficient between the scores of individuals on the two halves of the test and correcting the value of the parameter calculated by the (Sberman-Brown) equation The researcher has relied on the data of the main sample of the amendment, whose number is (125) male and female teachers in calculating stability in this way, as the statistical bag of social sciences (Spss) was used. Grades extracted represents stability for half of the test which is (0.832) and in order to get the reliability coefficient of the test as a whole was used equation (Spearman-Brown) to correct the correlation coefficient after correction became the reliability coefficient $(0.811)$, a coefficient of high stability and can be relied upon to estimate the test stability.

Fakronbach laboratories

The two researchers extract the stability by the Fakronbach coefficient based on the sample data for the construction of (120) and extract the coefficient of stability, whose value was for the strategic planning scale (0.698), which is a high reliability coefficient that can be trusted to estimate the stability of the test.

Objectivity:

If the questionnaire is set, it will be distinguished by objectivity, as it is far from the intervention of the researcher and his views, and this is confirmed by a number of specialists (the extent to which the examiner is liberated from subjective factors. Therefore, the two measures of the method in question are characterized by objectivity because there is a correction key to the alternatives to the answer.

The main experience of applying the strategic planning metrics:

After the scale became ready for application in its final form, Appendix (5), the researchers applied, with the assistance of the auxiliary team, the scale on the application sample of (76) members of an administrative body for the period from Thursday 19/9/2019 until Wednesday 9/25/2019.

\section{Statistical means:}

The researchers used the Statistical Bag of Social Sciences (Spss) -

.Arithmetic mean -

standard deviation.-

.test for independent samples -

Simple correlation coefficient.-

Coefficient of torsion.-

Factories of Fakrubach.-

.- Spearman Brown equation

\section{RESULT AND DISCUSSION:}

Display the results of the arithmetic mean, the standard deviations, the hypothesis mean, and the value (T) of the strategic planning scale

Table (7): The mean, standard deviation, (T) value and hypothetical mean of the strategic planning scale

\begin{tabular}{|c|c|c|c|c|c|c|}
\hline Significant & Error level & $\begin{array}{l}\text { Calculated } \mathrm{T} \\
\text { value }\end{array}$ & $\begin{array}{l}\text { The } \\
\text { hypothetical } \\
\text { medium }\end{array}$ & $\begin{array}{l}\text { standard } \\
\text { deviation }\end{array}$ & $\begin{array}{l}\text { Arithmetic } \\
\text { mean of the } \\
\text { sample }\end{array}$ & $\begin{array}{l}\text { the } \\
\text { number }\end{array}$ \\
\hline Not moral & 0.105 & 1.642 & 246 & 12.36381 & 243.6711 & 76 \\
\hline
\end{tabular}

Moral $\square$ of $(0,05)$ degree of freedom (75) 
Through table (7), the two researchers showed an insignificant response in the research sample for the strategic planning scale and through the results of the test $(\mathrm{T})$. When comparing the arithmetic and hypothesis of the scale there are no statistically significant differences, as the moral value (0.105) which is greater From the level of significance (0.05), in addition to that the level of the verified arithmetic is smaller than the hypothetical mean value of the scale and as in table (7), which indicates that the Iraqi Central Handball Federation has a limited and not good level of strategic planning and the researcher attributes that to the sample that was not Strategic planning is evident through their practices and managed $\mathrm{M}$, and her focus was focused on achieving planning according to the accepted programs to ensure its work on what exists and not on what it should be, as strategic planning is no longer a priority in developing the game. Moreover, the available environment is not feasible to manage strategic planning since the Iraqi Central Football Federation The hand lacks many elements and material capabilities, which are a source of obstacles to strategic planning, as well as the process of flow of information and the nature of continuous communication to solve problems inconsistent with the ability of those in charge of the handball game through adopting new ideas and supporting them financially and morally And turning them into practical programs that serve the game, as the world today falls within the information and communications revolution for change processes and pushing organizations to develop planning so that they can coexist and keep pace with the requirements of the future according to time variations, as Reem Al-Damen states, "Strategic planning tends to identify the strengths and weaknesses involved in the future, and take advantage of opportunities Available and avoid risks, then strategic planning here means design or model for the desired future and specifically the means leading to it (guarantor, 2004, page 37), since the regular thinking of problems in different circumstances adversely affects the planning process For a strategist as well as not to bring in experts related to this field from foreign federations that have a long tradition, as well as not to intensify training and workshops and exchange experiences through funded projects. "There are some obstacles that hinder the process of the resulting strategic planning, whether at the level of the Ministry of Youth and Sports, i.e. at the state level or At the level of youth and sports organizations, these obstacles may be contemporary to the process of developing the strategic plan "(Al-Aboudi, 2008, page 18)

The researchers believe that this problem exists in most sports federations, and in order to address them, a network of information and means of communication and the existence of modern human and electronic capabilities and capabilities will be provided to provide those in charge of strategic planning with the most recent and most reliable information and data, and that this last be sufficient, and this data includes all aspects that are related to or related to it. The Iraqi Central Handball Federation, in addition to the technical need as a handicap in the way of implementing the strategic plans, may occur, after the plan has been developed according to sound estimates and expectations and based on accurate data and information that implies some technical difficulties. Which is the lack of validity of estimating the size and types of material resources, and the error in the recruitment and use of physical materials and error in determining spending priorities and directing spending to marginal purposes affect the plan, progress towards achieving its objectives.

The view of the members of the Central Iraqi Handball Federation that the formulation and clarity of the goals of strategic planning in the federation are not consistent with the expected expectations, as well as the administrators and workers and their capabilities as well as other capabilities available to them from administrations and they need the administration to be interested in stimulating their participation when formulating these goals, to be able to After that the goals of strategic planning direct the duties of workers within the union and provide them with a real opportunity to share their ideas in formulating the goals of this planning in a way that is compatible with the possibility of their implementation, as the clarity of formulating the goals is the basis for any process that is intended Here success can not be unilaterally drafted without the involvement of workers who seek to develop the EU output as little super dream "determines the planning objectives that the organization seeks to achieve precisely and clearly in line with the capabilities of the organization and the resources available and projected. (Papillary 2004, p. 41)

\section{CONCLUSIONS:}

- Building and applying the strategic planning scale, which consisted of (82) paragraphs, was reached.

- Lack of seriousness and taking into consideration the basic principles of strategic planning.

- Strategic planning plays an important role in changing and developing the Iraqi Central Handball Federation. 


\section{ENDORSEMENT:}

- The scale is continuously applied by the Iraqi Federation to identify the extent to which the strategic planning has reached.

- Emphasizing the strategic planning of the Iraqi Central Handball Federation, exchanging ideas and information on an ongoing basis, and trying to reformulate it to serve it.

.Adopting the modern standard to identify the reality of strategic planning -

- Applying the standard to other unions at the level of Iraq and all the games.

\section{REFERENCES:}

- Ahmed Suleiman Odeh. (1998). Measurement and evaluation in the teaching process. Irbid: Dar Al Amal.

- Reem the guarantor. (2004). School Development Plan Building Guide. Amman, Amman, Jordan: Agency Presidency.

- Zaid Munir Al-Aboudi. (2008). Administrative planning and development. Amman: Dar Al-Raya.

- Hussein KamelAboud. Building and legalizing the measure of alienation among some athletes, individual and teams, doctoral thesis, University of Baghdad, 2008.

- Muhammad Hassan Allawi and Nasr al-Din Radwan. (2009). Measurement in physical education and educational psychology. Cairo: Dar Al-Fikr Al-Arabi.

- FaiqHusni Abu Halima, Hadith in the Sports Administration, Wael House for Publishing and Distribution, Amman (2004).

\section{Annex (1)}

Personal interviews to seek expert opinions

\begin{tabular}{|c|c|c|c|}
\hline Workplace & Jurisdiction & $\begin{array}{l}\text { The name of the expert and } \\
\text { the scientific title }\end{array}$ & sequence \\
\hline $\begin{array}{llr}\text { University of Baghdad / } & \text { of } \\
\text { College of Physical } \\
\text { Education and } \\
\text { Sciences }\end{array}$ & Training / hand & $\begin{array}{l}\text { Prof. Dr. Abdul Wahab } \\
\text { Ghazi }\end{array}$ & 1 \\
\hline $\begin{array}{llr}\text { University of Baghdad / } \\
\text { College of Physical } \\
\text { Education and Sports } \\
\text { Sciences }\end{array}$ & Management and Organization & Prof. Dr. Abdullah Hazza & 2 \\
\hline $\begin{array}{l}\text { University of Baghdad / } \\
\text { College of Physical } \\
\text { Education and Sports } \\
\text { Sciences }\end{array}$ & $\begin{array}{l}\text { Management and organization / } \\
\text { basket }\end{array}$ & Prof. QusaiFawzi & 3 \\
\hline $\begin{array}{llr}\text { University of } & \text { Baghdad / } \\
\text { College of } & \text { Physical } \\
\text { Education } & \text { and } & \text { Sports } \\
\text { Sciences } & & \end{array}$ & Management and Organization & $\begin{array}{ll}\text { Assist.Prof.DR. } & \text { Salah } \\
\text { Wahhab Al Kindy } & \end{array}$ & 4 \\
\hline University of Baghdad / & Management and Organization & Assist.Prof.DR. $\quad$ Salam & 5 \\
\hline
\end{tabular}




College of $\begin{array}{r}\text { Physical } \\ \text { Education and } \\ \text { Sciences }\end{array}$

SalamHantoush Rashid

Annex (2)

Experts and specialists in the field of sports management, handball, measurement and evaluation

\begin{tabular}{|c|c|c|c|}
\hline Workplace & Jurisdiction & The name & sequence \\
\hline $\begin{array}{l}\text { College of Physical Education and Sports } \\
\text { Science / University of Baghdad }\end{array}$ & Training / hand & $\begin{array}{l}\text { Prof. Dr. Abdul Wahab } \\
\text { Ghazi }\end{array}$ & 1 \\
\hline $\begin{array}{l}\text { College of Physical Education and Sports } \\
\text { Science / University of Baghdad }\end{array}$ & $\begin{array}{l}\text { Management } \\
\text { Organization }\end{array}$ & Prof. Dr. Abdullah Hazza & 2 \\
\hline $\begin{array}{l}\text { College of Physical Education and Sports } \\
\text { Sciences / University of Basra }\end{array}$ & $\begin{array}{l}\text { Management and } \\
\text { organization / basket }\end{array}$ & Prof. QusaiFawzi & 3 \\
\hline $\begin{array}{l}\text { College of Physical Education and Sports } \\
\text { Science / University of Baghdad }\end{array}$ & $\begin{array}{l}\text { Test and measure / } \\
\text { basket }\end{array}$ & Prof. Fares Yousef Sami & 4 \\
\hline $\begin{array}{l}\text { College of Physical Education and Sports } \\
\text { Science / Anbar University }\end{array}$ & $\begin{array}{l}\text { Teaching methods and } \\
\text { methods }\end{array}$ & $\begin{array}{l}\text { Prof. Waed Abdul Rahim } \\
\text { Farhan }\end{array}$ & 5 \\
\hline Peace College & Sports management & $\begin{array}{l}\text { Prof. Ibrahim Younes } \\
\text { and Kaaa }\end{array}$ & 6 \\
\hline $\begin{array}{l}\text { College of Physical Education and Sports } \\
\text { Science / University of Samawah }\end{array}$ & Sports management & Dr. Khaled Aswad & 7 \\
\hline Helwan University & Sports management & $\begin{array}{l}\text { Prof. Ahmed El-Sayed } \\
\text { Metwally }\end{array}$ & 8 \\
\hline Alexandria University & Sports management & Prof. Hassan El-Shafei & 9 \\
\hline $\begin{array}{l}\text { College of Physical Education and Sports } \\
\text { Science / Diyala University }\end{array}$ & $\begin{array}{l}\text { Sports / Airplane } \\
\text { Management }\end{array}$ & $\begin{array}{l}\text { Prof. } \\
\text { NaseerQasimKhalaf }\end{array}$ & 10 \\
\hline $\begin{array}{l}\text { College of Physical Education and Sports } \\
\text { Sciences / University of Basra }\end{array}$ & Training / basket & $\begin{array}{lll}\text { Prof. } & \text { Haider } & \text { Abdul } \\
\text { Razzaq } & & \end{array}$ & 11 \\
\hline $\begin{array}{l}\text { College of Physical Education and Sports } \\
\text { Science / University of Baghdad }\end{array}$ & $\begin{array}{l}\text { Tests } \\
\text { measurement }\end{array}$ & Prof. Zahra Shihab & 12 \\
\hline $\begin{array}{l}\text { College of Physical Education and Sports } \\
\text { Science for Girls / University of Baghdad }\end{array}$ & Modalities / hand & $\begin{array}{l}\text { Prof. Iqbal Abdul } \\
\text { Hussein blessing }\end{array}$ & 13 \\
\hline $\begin{array}{l}\text { College of Administration and Economics / } \\
\text { University of Baghdad }\end{array}$ & General management & $\begin{array}{l}\text { Prof. Salah Hamid Al- } \\
\text { Kubaisi }\end{array}$ & 14 \\
\hline $\begin{array}{l}\text { College of Physical Education and Sports } \\
\text { Sciences / University of Basra }\end{array}$ & Sports management & $\begin{array}{l}\text { Prof. Fouad Abdel- } \\
\text { Mahdi }\end{array}$ & 15 \\
\hline $\begin{array}{l}\text { College of Physical Education and Sports } \\
\text { Science for Girls / University of Baghdad }\end{array}$ & Training / fencing & $\begin{array}{lll}\text { Prof. } & \text { Fatima } & \text { Abdel } \\
\text { Maleh } & & \end{array}$ & 16 \\
\hline $\begin{array}{l}\text { College of Physical Education and Sports } \\
\text { Science / University of Baghdad }\end{array}$ & Bayou / basket & Prof. Hoda Hamid & 17 \\
\hline $\begin{array}{l}\text { College of Physical Education and Sports } \\
\text { Science / University of Baghdad }\end{array}$ & $\begin{array}{l}\text { Management } \\
\text { Organization }\end{array}$ & $\begin{array}{l}\text { Prof. Salah Wahhab Al } \\
\text { Kindy }\end{array}$ & 18 \\
\hline
\end{tabular}




\begin{tabular}{|c|c|c|c|}
\hline $\begin{array}{l}\text { College of Physical Education and Sports } \\
\text { Science / Al-Mustansiriya University }\end{array}$ & $\begin{array}{l}\text { Management } \\
\text { Organization }\end{array}$ & $\begin{array}{l}\text { Prof. Salam } \\
\text { SalamHantoush Rashid }\end{array}$ & 19 \\
\hline $\begin{array}{l}\text { College of Physical Education and Sports } \\
\text { Science / University of Baghdad }\end{array}$ & $\begin{array}{l}\text { Tests and } \\
\text { measurement / plane }\end{array}$ & $\begin{array}{l}\text { Prof. AsmaHikmat Al- } \\
\text { Samarrai }\end{array}$ & 20 \\
\hline $\begin{array}{l}\text { College of Physical Education and Sports } \\
\text { Science / Sulaymaniyah University }\end{array}$ & Dynamic learning & Prof. Dr. On Ahmed Fagr & 21 \\
\hline $\begin{array}{l}\text { College of Physical Education and Sports } \\
\text { Science / University of Kirkuk }\end{array}$ & Dynamic learning & $\begin{array}{ll}\text { Prof. } & \text { Dr. } \\
\text { QurabiaFaeqQasim } & \end{array}$ & 22 \\
\hline $\begin{array}{l}\text { College of Physical Education and Sports } \\
\text { Science for Girls / University of Baghdad }\end{array}$ & $\begin{array}{l}\text { Tests } \\
\text { measurement }\end{array}$ & $\begin{array}{l}\text { Prof. Dr. Warda Ali } \\
\text { Abbas }\end{array}$ & 23 \\
\hline $\begin{array}{l}\text { College of Physical Education and Sports } \\
\text { Science for Girls / University of Baghdad }\end{array}$ & $\begin{array}{l}\text { Management and } \\
\text { organization / aircraft }\end{array}$ & $\begin{array}{lll}\text { Prof. } & \text { Sundus } & \text { Musa } \\
\text { Jawad } & & \end{array}$ & 24 \\
\hline $\begin{array}{l}\text { College of Physical Education and Sports } \\
\text { Science / University of Baghdad }\end{array}$ & Athletic management & a. M Ali Abdul Latif & 25 \\
\hline $\begin{array}{l}\text { College of Physical Education and Sports } \\
\text { Science / University of Baghdad }\end{array}$ & $\begin{array}{l}\text { Tests and } \\
\text { measurement / plane }\end{array}$ & $\begin{array}{l}\text { Dr. Khalil Starr } \\
\text { Muhammad }\end{array}$ & 26 \\
\hline $\begin{array}{l}\text { College of Physical Education and Sports } \\
\text { Science / University of Baghdad }\end{array}$ & Athletic management & $\begin{array}{l}\text { Dr. } \\
\text { ThamerHammadRajeh }\end{array}$ & 27 \\
\hline $\begin{array}{l}\text { College of Physical Education and Sports } \\
\text { Science / University of Baghdad }\end{array}$ & Psychology / footing & Dr. Ahmed Thari Hani & 28 \\
\hline $\begin{array}{l}\text { College of Physical Education and Sports } \\
\text { Science / University of Sulaymaniyah }\end{array}$ & Sports management & Dr. Diyar Kamal Asaad & 29 \\
\hline
\end{tabular}

\section{Annex (3)}

A special questionnaire for the purpose of determining the most important areas and paragraphs for the scale of strategic planning

Ministry of Higher Education and Scientific Research

College of Physical Education and Sports Science for Girls

Postgraduate / PhD

M / Astpana to determine the validity of the scale fields and its paragraphs

Mr. Professor . Respected

good greeting

The two researchers intend to conduct its research tagged (the reality of strategic planning for the Central Iraqi Federation by hand from the point of view of the administrative bodies of the clubs)

The researchers hope to define the areas of the scale and its paragraphs for strategic planning for the Central Iraqi Federation by hand. The strategic planning is defined as "(defining the vision and mission and setting strategic goals and strategies that allow their achievement and controlling how to evaluate the achievements achieved) And given your scientific and practical experience in this field, please show The opinion on the validity of the fields and paragraphs of the scale attached hereto by placing a mark $(\sqrt{ })$ in the field is valid or invalid, with mentioning notes if there are five alternatives for each paragraph. Tiered as shown in the table.

\begin{tabular}{|l|l|l|l|l|}
\hline Start & Scarcely & Sometimes & Always & $\begin{array}{l}\text { Direction of the } \\
\text { vertebrae }\end{array}$ \\
\hline & & & the \\
& & & Peight \\
\hline
\end{tabular}


Thank you very much.

Signature:

Name and scientific surname: The two researchers

Jurisdiction:

Workplace:

Areas and paragraphs of the strategic planning scale

\begin{tabular}{|c|c|c|c|c|}
\hline Notes & Does not fit & Repair & the field & sequence \\
\hline & & & $\begin{array}{l}\text { Clarity of mission: The message reflects } \\
\text { the philosophy and aspirations of the } \\
\text { Union. }\end{array}$ & 1 \\
\hline & & & $\begin{array}{l}\text { Clarity of vision: aspirations and } \\
\text { developments for what should be the union } \\
\text { in the future }\end{array}$ & 2 \\
\hline & & & $\begin{array}{l}\text { Objectives: the outcome that the Union is } \\
\text { striving to achieve. }\end{array}$ & 3 \\
\hline & & & $\begin{array}{l}\text { Evaluating strategic plans: how successful } \\
\text { the union has in its strategic choice }\end{array}$ & 4 \\
\hline & & & $\begin{array}{l}\text { Monitoring and follow-up: These are the } \\
\text { processes of continuous organizational } \\
\text { control over the implementation of the } \\
\text { union's strategies }\end{array}$ & 5 \\
\hline & & & $\begin{array}{l}\text { Internal and external environment analysis: } \\
\text { it is an analysis that is conducted to } \\
\text { identify the strengths and weaknesses } \\
\text { within the union }\end{array}$ & 6 \\
\hline & & & $\begin{array}{l}\text { Information and communication systems: } \\
\text { Existence of accurate, comprehensive data, } \\
\text { information and communication for all } \\
\text { aspects of the Union }\end{array}$ & 7 \\
\hline & & & $\begin{array}{l}\text { Organizational Structure: Organizational } \\
\text { structure means the framework or structure } \\
\text { that defines the internal structure of the } \\
\text { Union }\end{array}$ & 8 \\
\hline & & & $\begin{array}{l}\text { Financing and financial management: it is } \\
\text { all available administrative and financial } \\
\text { capabilities to implement the strategic plan }\end{array}$ & 9 \\
\hline & & & $\begin{array}{l}\text { Implementation of strategic plans: a } \\
\text { process that complements the previous } \\
\text { operations that the federation chose to } \\
\text { implement in practice }\end{array}$ & 10 \\
\hline & & & $\begin{array}{l}\text { Evaluation: the process of obtaining data } \\
\text { and using it to form judgments, which in } \\
\text { turn is used in the decision-making process }\end{array}$ & 11 \\
\hline
\end{tabular}


The first area is the clarity of the message: the message reflects the Federation's philosophy and aspirations that can be achieved at the present time and clarifies the nature of the activities that it is interested in and reflects the justifications for its origin and identity that are unique to it and includes a group of paragraphs

\begin{tabular}{|c|c|c|c|c|}
\hline Notes & write off & Serve & Paragraph & sequence \\
\hline & & & $\begin{array}{l}\text { The message of the federation } \\
\text { is in line with its available } \\
\text { capabilities. }\end{array}$ & 1 \\
\hline & & & $\begin{array}{l}\text { The Union publishes its } \\
\text { message clearly and in writing } \\
\text { in its various branches inside } \\
\text { Iraq. }\end{array}$ & 2 \\
\hline & & & $\begin{array}{l}\text { The mission of the Union's } \\
\text { strategic planning is } \\
\text { comprehensive and realistic. }\end{array}$ & 3 \\
\hline & & & $\begin{array}{l}\text { The mission of the Union's } \\
\text { strategic planning is in line } \\
\text { with its objectives. }\end{array}$ & 4 \\
\hline & & & $\begin{array}{l}\text { The mission of strategic } \\
\text { planning expresses the current } \\
\text { and future philosophy of the } \\
\text { Union. }\end{array}$ & 5 \\
\hline & & & $\begin{array}{l}\text { The mission of the Federation } \\
\text { includes the ability to embed } \\
\text { values and beliefs in a manner } \\
\text { appropriate to strategic } \\
\text { planning. }\end{array}$ & 6 \\
\hline & & & $\begin{array}{l}\text { The Federation's strategic } \\
\text { planning mission includes } \\
\text { building on past experiences. }\end{array}$ & 7 \\
\hline & & & $\begin{array}{l}\text { The Federation's mission } \\
\text { includes the main activities } \\
\text { and services entrusted to it. }\end{array}$ & 8 \\
\hline
\end{tabular}

The second area is the clarity of the vision: As for the vision, it is the aspirations and developments of what the union must have in the future. These aspirations cannot be achieved at the present time, but it is postponed in the future

\begin{tabular}{|l|l|l|l|l|}
\hline Notes & write off & Serve & Paragraph \\
\hline & & $\begin{array}{l}\text { The future vision for strategic planning is realistic and } \\
\text { clear }\end{array}$ \\
\hline & $\begin{array}{l}\text { The union creates an ambitious and attractive vision of } \\
\text { its future image }\end{array}$ \\
\hline & $\begin{array}{l}\text { The Federation vision aims to diversify all services that } \\
\text { would meet the ambitions of clubs and national teams }\end{array}$ \\
\hline & $\begin{array}{l}\text { The Federation vision seeks to achieve excellence in its } \\
\text { work through its administrative excellence }\end{array}$ \\
\hline & The Federation's vision is concerned with increasing its & $\mathbf{5}$ \\
\hline
\end{tabular}




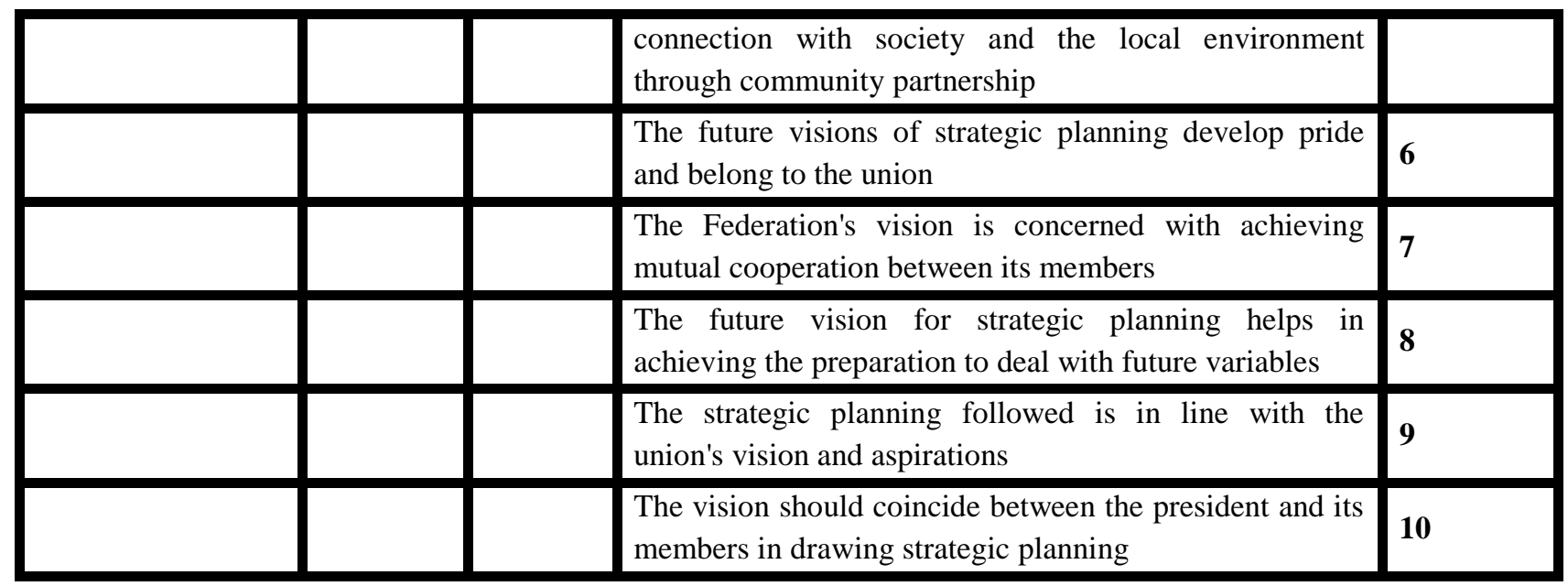

The third area: The objectives: the output that the union struggles to achieve, which is a sentence that defines a desired or targeted result that represents what must be accomplished and when

\begin{tabular}{|c|c|c|c|c|}
\hline Notes & write off & Serve & Paragraph & sequence \\
\hline & & & $\begin{array}{l}\text { The Union sets realistic strategic goals that it } \\
\text { derives from its mission }\end{array}$ & 1 \\
\hline & & & $\begin{array}{l}\text { The Union sets its strategic goals according to } \\
\text { specific criteria for assessing progress in } \\
\text { work }\end{array}$ & 2 \\
\hline & & & $\begin{array}{l}\text { The Union divides its objectives into an } \\
\text { integrated short and long term phase }\end{array}$ & 3 \\
\hline & & & $\begin{array}{l}\text { The formulation of strategic planning goals } \\
\text { takes into account the administrative } \\
\text { formation of the federation }\end{array}$ & 4 \\
\hline & & & $\begin{array}{l}\text { The goals of strategic planning define the } \\
\text { Union for the Olympic Committee in which it } \\
\text { operates }\end{array}$ & 5 \\
\hline & & & $\begin{array}{l}\text { Involve all Union members in the process of } \\
\text { setting strategic planning goals }\end{array}$ & 6 \\
\hline & & & $\begin{array}{l}\text { The goals of strategic planning contribute to } \\
\text { the accuracy of the Federation's work }\end{array}$ & 7 \\
\hline & & & $\begin{array}{l}\text { The goals of strategic planning act as } \\
\text { incentives for members of the Union }\end{array}$ & 8 \\
\hline & & & $\begin{array}{l}\text { The strategic goals are the foundation upon } \\
\text { which the Union builds its future policy }\end{array}$ & 9 \\
\hline & & & $\begin{array}{l}\text { The goals of strategic planning must be clear } \\
\text { and understandable, clearly stating what } \\
\text { needs to be done }\end{array}$ & 10 \\
\hline
\end{tabular}

The fourth area is evaluation of strategic planning: It is a process carried out by the federation to determine the success of its strategic choice through an integrated control system in terms of the authority responsible for it, the means and 
methods used in it and methods of intervention to find out the obstacles to implementation and diagnose their causes and work to avoid them in future plans

\begin{tabular}{|c|c|c|c|c|}
\hline Notes & write off & Serve & Paragraph & sequence \\
\hline & & & $\begin{array}{l}\text { The Federation reviews the strategies and plans } \\
\text { it implements in light of the continuous } \\
\text { monitoring of internal and external changes }\end{array}$ & 1 \\
\hline & & & $\begin{array}{l}\text { The Federation shall determine the committee } \\
\text { or individuals authorized to follow up the } \\
\text { implementation of the set plans. }\end{array}$ & 2 \\
\hline & & & $\begin{array}{l}\text { The federation adopts various methods for } \\
\text { monitoring and evaluating actual performance } \\
\text { and comparing it with the expected. }\end{array}$ & 3 \\
\hline & & & $\begin{array}{l}\text { The Union uses regulatory information to build } \\
\text { its future plans. }\end{array}$ & 4 \\
\hline & & & $\begin{array}{l}\text { The Federation identifies the obstacles and } \\
\text { problems facing its plans. }\end{array}$ & 5 \\
\hline & & & $\begin{array}{l}\text { The federation relies on the system of the issue } \\
\text { of those involved in the implementation, in a } \\
\text { transparent manner, on the level of their } \\
\text { performance and achieving the results expected } \\
\text { of them. }\end{array}$ & 6 \\
\hline & & & $\begin{array}{l}\text { Continuous evaluation when implementing } \\
\text { strategic plans. }\end{array}$ & 7 \\
\hline & & & $\begin{array}{l}\text { How credible is the union system in assessing } \\
\text { its employees? }\end{array}$ & 8 \\
\hline & & & $\begin{array}{l}\text { Are incentives and rewards linked to employee } \\
\text { performance levels and evaluation results? }\end{array}$ & 9 \\
\hline & & & $\begin{array}{l}\text { Does the federation leadership have a clear } \\
\text { evaluation policy? }\end{array}$ & 10 \\
\hline
\end{tabular}

Fifth Domain: Monitoring and Follow-up: These are the continuous organizational control processes to implement the Federation's strategies effectively and in a way that ensures the achievement of the Union's mission and strategic goals

\begin{tabular}{|c|c|c|c|c|}
\hline Notes & $\begin{array}{l}\text { write } \\
\text { off }\end{array}$ & Serve & Paragraph & sequence \\
\hline & & & $\begin{array}{l}\text { Correct action is taken when monitoring for the short, } \\
\text { medium, and long term to implement strategic plans. }\end{array}$ & 1 \\
\hline & & & $\begin{array}{l}\text { Control mainly focuses on the outputs of the planning } \\
\text { process within strategic planning processes. }\end{array}$ & 2 \\
\hline & & & Control is an ongoing process of measuring performance. & 3 \\
\hline & & & $\begin{array}{l}\text { The lack of committees operating in the Federation to } \\
\text { follow up on various activities. }\end{array}$ & 4 \\
\hline & & & $\begin{array}{l}\text { Is the monitoring system followed by the Federation } \\
\text { inaccurate? }\end{array}$ & 5 \\
\hline
\end{tabular}




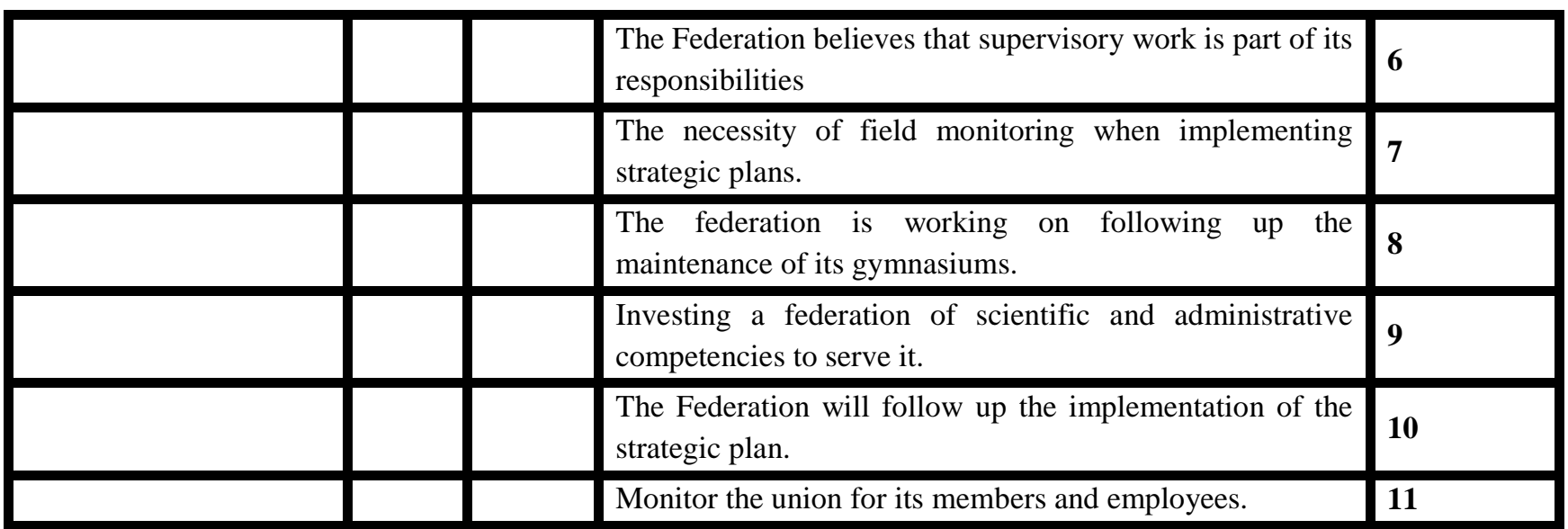

The Sixth Field Analysis of the internal and external environment: It is an analysis that is conducted to identify the strengths and weaknesses within the Federation regarding its resources, activities, operations and work systems. As for the external analysis, it is the identification of opportunities and threats that exist in the external environment of the Union

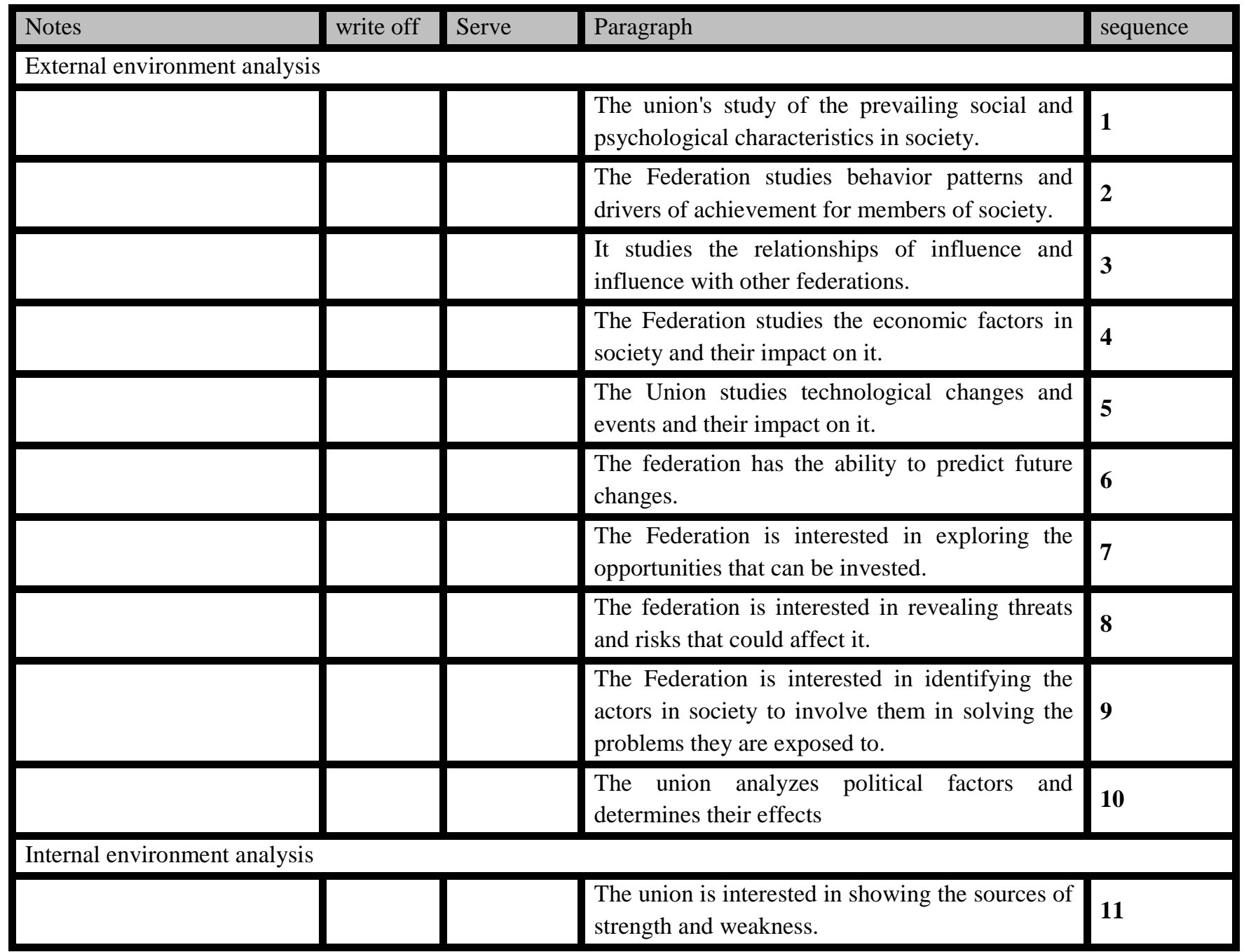




\begin{tabular}{|l|l|l|l|}
\hline & & $\begin{array}{l}\text { The Federation identifies the critical issues you } \\
\text { face. }\end{array}$ & $\mathbf{1 2}$ \\
\hline & & $\begin{array}{l}\text { The Federation studies the level of professional } \\
\text { competencies of all workers in the Union. }\end{array}$ & $\mathbf{1 3}$ \\
\hline & & $\begin{array}{l}\text { The Federation is concerned with the availability } \\
\text { of administrative systems in it. }\end{array}$ & $\mathbf{1 4}$ \\
\hline & $\begin{array}{l}\text { The Federation was keen to provide a rich and } \\
\text { effective culture. }\end{array}$ & $\mathbf{1 5}$ \\
\hline & $\begin{array}{l}\text { Attention to the effectiveness of the } \\
\text { organizational structure of the Federation. }\end{array}$ & $\mathbf{1 6}$ \\
\hline & $\begin{array}{l}\text { The Federation's interest in providing its own } \\
\text { database. }\end{array}$ & $\mathbf{1 7}$ \\
\hline & $\begin{array}{l}\text { The Federation's study of the efficiency of its } \\
\text { buildings, facilities and equipment. }\end{array}$ & $\mathbf{1 8}$ \\
\hline & \begin{tabular}{l} 
The Federation's interest in administrative needs. \\
\hline
\end{tabular} & $\begin{array}{l}\text { The Federation's interest in sensing the } \\
\text { psychological and social needs of workers and } \\
\text { striving to meet them. }\end{array}$ & $\mathbf{2 0}$ \\
\hline
\end{tabular}

The seventh field Information and communication systems: The strategic planning process is based on the presence of accurate, comprehensive data, information and communications for all aspects of the Union in which the strategic plan will be applied

\begin{tabular}{|c|c|c|c|c|}
\hline Notes & write off & Serve & Paragraph & sequence \\
\hline & & & The need for databases in the Federation. & 1 \\
\hline & & & $\begin{array}{l}\text { The need for advanced information systems, } \\
\text { communication devices and systems in the } \\
\text { Federation }\end{array}$ & 2 \\
\hline & & & $\begin{array}{l}\text { The need for the union to follow, archive and } \\
\text { document data and communications. }\end{array}$ & 3 \\
\hline & & & $\begin{array}{l}\text { The need for a system to store, handle and recall } \\
\text { documents. }\end{array}$ & 4 \\
\hline & & & $\begin{array}{l}\text { The need to have a system to provide } \\
\text { information to players clearly. }\end{array}$ & 5 \\
\hline & & & $\begin{array}{l}\text { The necessity of using modern communication } \\
\text { systems to support information systems. }\end{array}$ & 6 \\
\hline & & & $\begin{array}{l}\text { The necessity of providing the Union with } \\
\text { sufficient information about its programs and } \\
\text { activities for the beneficiaries? }\end{array}$ & 7 \\
\hline & & & $\begin{array}{l}\text { The importance of modernizing and developing } \\
\text { the communication devices in the Union. }\end{array}$ & 8 \\
\hline & & & $\begin{array}{l}\text { The need for ITU to provide effective } \\
\text { communication systems for safekeeping of } \\
\text { information. }\end{array}$ & 9 \\
\hline
\end{tabular}




\begin{tabular}{|l|l|l|l|l|l|l|}
\hline & $\begin{array}{l}\text { The need for policies to preserve the privacy of } \\
\text { ITU records. }\end{array}$ \\
\hline & $\begin{array}{l}\text { There are backup copies of the official records } \\
\text { of the Federation for preservation outside the } \\
\text { Federation. }\end{array}$ \\
\hline & $\begin{array}{l}\text { Development of database systems based on } \\
\text { defining the needs of the Union. }\end{array}$ \\
\hline & $\begin{array}{l}\text { The Federation's database systems are reviewed } \\
\text { and evaluated. }\end{array}$ \\
\hline $\begin{array}{l}\text { Database systems are upgraded and maintained } \\
\text { based on the results of the audit and evaluation. }\end{array}$ & $\mathbf{1 4}$ \\
\hline
\end{tabular}

The Eighth Domain Organizational Structure: The organizational structure means that it is the framework or structure that defines the internal structure of the Union, as it clarifies the divisions, organizations and sub-units that perform the various actions and activities necessary to achieve the goals of the Union

\begin{tabular}{|c|c|c|c|c|}
\hline Notes & write off & Serve & Paragraph & sequence \\
\hline & & & $\begin{array}{l}\text { The organizational structure of the federation is } \\
\text { proportional to being a civil society } \\
\text { organization. }\end{array}$ & 1 \\
\hline & & & $\begin{array}{l}\text { The importance of legal frameworks (legal } \\
\text { procedures) for adopting or updating the } \\
\text { organizational structure of the federation. }\end{array}$ & 2 \\
\hline & & & $\begin{array}{l}\text { The organizational structure of the Union is } \\
\text { marked by clear lines of authority and } \\
\text { responsibility. }\end{array}$ & 3 \\
\hline & & & $\begin{array}{l}\text { The necessity of accurate identification of the } \\
\text { responsibilities of academic and administrative } \\
\text { leaders in the Federation. }\end{array}$ & 4 \\
\hline & & & $\begin{array}{l}\text { The necessity of documenting these } \\
\text { responsibilities in the Federation guide. }\end{array}$ & 5 \\
\hline & & & $\begin{array}{l}\text { The necessity of the federation's structure to } \\
\text { depend on the delegation of powers. }\end{array}$ & 6 \\
\hline & & & $\begin{array}{l}\text { The need to clarify the tasks and responsibilities } \\
\text { of all members of the Union. }\end{array}$ & 7 \\
\hline & & & $\begin{array}{l}\text { The necessity of the Union administration to be } \\
\text { satisfied with the beneficiaries }\end{array}$ & 8 \\
\hline & & & $\begin{array}{l}\text { The necessity of modernizing the structures } \\
\text { based on studying the needs required for the } \\
\text { union }\end{array}$ & 9 \\
\hline & & & $\begin{array}{l}\text { The need for employees to be familiarized with } \\
\text { organizational structures and job descriptions }\end{array}$ & 10 \\
\hline
\end{tabular}


The ninth field: Finance and financial management is all available administrative and financial capabilities to implement the strategic plan

\begin{tabular}{|c|c|c|c|c|}
\hline Notes & write off & Serve & Paragraph & sequence \\
\hline & & & $\begin{array}{l}\text { The Federation's commitment to prepare an } \\
\text { appropriate and detailed annual budget and a } \\
\text { statement of the expected income and expenses } \\
\text { represented by the Federation's fiscal year. }\end{array}$ & 1 \\
\hline & & & $\begin{array}{l}\text { The federation uses its resources and capabilities } \\
\text { to achieve its goals. }\end{array}$ & 2 \\
\hline & & & $\begin{array}{l}\text { The Federation has been affected in taking its } \\
\text { decisions and actions with the financial resources } \\
\text { granted to it. }\end{array}$ & 3 \\
\hline & & & $\begin{array}{l}\text { The procedures for determining financial } \\
\text { resources and their uses are subject to regular } \\
\text { periodic evaluation. }\end{array}$ & 4 \\
\hline & & & $\begin{array}{l}\text { The union guarantees its financial stability for the } \\
\text { success of its various operations and activities. }\end{array}$ & 5 \\
\hline & & & $\begin{array}{l}\text { The financial resources available annually are } \\
\text { sufficient for the Union to achieve its mission, } \\
\text { goals and strategic goals. }\end{array}$ & 6 \\
\hline & & & $\begin{array}{l}\text { Existence of financial systems and regulations } \\
\text { governing the performance of the Union's } \\
\text { financial management. }\end{array}$ & 7 \\
\hline & & & $\begin{array}{l}\text { Existence of a system for controlling the budget } \\
\text { and financial affairs of the federation in a manner } \\
\text { that secures the implementation of the federation's } \\
\text { administrative committee's budget plans. }\end{array}$ & 8 \\
\hline & & & $\begin{array}{l}\text { The federation adopts an accounting system that } \\
\text { adopts the accepted accounting principles. }\end{array}$ & 9 \\
\hline & & & $\begin{array}{l}\text { The annual financial auditing process is subject to } \\
\text { certified chartered accountants. }\end{array}$ & 10 \\
\hline
\end{tabular}

The tenth area: implementation of the strategy, which is a complementary process to the previous operations that the federation chose to implement in practice

\begin{tabular}{|c|c|c|c|c|}
\hline Notes & write off & Serve & Paragraph & sequence \\
\hline & & & $\begin{array}{l}\text { The Union establishes the necessary policies to } \\
\text { implement the strategic plan. }\end{array}$ & 1 \\
\hline & & & The Union defines the main tasks to be performed. & 2 \\
\hline & & & $\begin{array}{l}\text { The Federation distributes tasks to the members } \\
\text { and determines the responsibility of each one of } \\
\text { them. }\end{array}$ & 3 \\
\hline & & & Coordination between members during the & 4 \\
\hline
\end{tabular}




\begin{tabular}{|c|c|c|c|}
\hline & & implementation of the strategic plan. & \\
\hline & & $\begin{array}{l}\text { The Federation designs an accurate management } \\
\text { information system that can be used during the } \\
\text { implementation process. }\end{array}$ & 5 \\
\hline & & $\begin{array}{l}\text { The Union designs a program to implement the } \\
\text { various operations and activities. }\end{array}$ & 6 \\
\hline & & $\begin{array}{l}\text { The Union shall determine the appropriate } \\
\text { performance criteria, whether quantitative or } \\
\text { qualitative. }\end{array}$ & 7 \\
\hline & & $\begin{array}{l}\text { The Union lays down the principles and principles } \\
\text { for the allocation and allocation of resources. }\end{array}$ & 8 \\
\hline & & $\begin{array}{l}\text { The Union establishes a system of reward stimulus } \\
\text { linked to the amount of achievement and progress } \\
\text { in implementing the strategy. }\end{array}$ & 9 \\
\hline & & $\begin{array}{l}\text { The Union establishes a precise, clear and fair } \\
\text { system of punishment and deterrence to prevent or } \\
\text { limit mistakes. }\end{array}$ & 10 \\
\hline & & $\begin{array}{l}\text { Improving the relationship between employees of } \\
\text { the union guarantees the progress of work and its } \\
\text { capabilities. }\end{array}$ & 11 \\
\hline & & $\begin{array}{l}\text { The Federation delegates some tasks to the } \\
\text { workers, each according to its ability and } \\
\text { capabilities. }\end{array}$ & 12 \\
\hline & & $\begin{array}{l}\text { The Federation resolves all the existing } \\
\text { interactions between the different fields and } \\
\text { functional activities in line with the requirements } \\
\text { of implementing the strategic plan }\end{array}$ & 13 \\
\hline & & $\begin{array}{l}\text { The strategy is advertised in a manner appropriate } \\
\text { to all relevant parties. }\end{array}$ & 14 \\
\hline
\end{tabular}

The eleventh area: evaluation: the process of obtaining data and using it to form judgments, which in turn is used in the decision-making process

\begin{tabular}{|l|l|l|l|l|}
\hline Notes & write off & Serve & Paragraph & sequence \\
\hline & & $\begin{array}{l}\text { Develop realistic and specific performance } \\
\text { standards. }\end{array}$ & $\mathbf{1}$ \\
\hline & & $\begin{array}{l}\text { The performance of the union is compared to the } \\
\text { standards set periodically. }\end{array}$ & $\mathbf{2}$ \\
\hline & & $\begin{array}{l}\text { The association compares its performance with } \\
\text { that of other federations locally and globally }\end{array}$ & $\mathbf{3}$ \\
\hline & $\begin{array}{l}\text { The federation compares its performance with } \\
\text { institutions known for its excellence in certain } \\
\text { fields. }\end{array}$ & $\mathbf{4}$ \\
\hline & \begin{tabular}{l} 
The federation is keen to take feedback of its \\
\hline
\end{tabular} & $\mathbf{5}$ \\
\hline
\end{tabular}




\begin{tabular}{|c|c|c|c|}
\hline & & $\begin{array}{l}\text { performance from the bodies that benefit from its } \\
\text { services }\end{array}$ & \\
\hline & & $\begin{array}{l}\text { Feedback from the performance of the Federation } \\
\text { is taken from its members and affiliates }\end{array}$ & 6 \\
\hline & & $\begin{array}{l}\text { The players 'feedback from players is taken into } \\
\text { consideration. }\end{array}$ & 7 \\
\hline & & $\begin{array}{l}\text { The evaluation system provides the information } \\
\text { necessary to make decisions in a timely manner }\end{array}$ & 8 \\
\hline & & $\begin{array}{l}\text { Procedures and practices are adjusted in light of } \\
\text { the evaluation findings. }\end{array}$ & 9 \\
\hline & & $\begin{array}{l}\text { Plans and objectives are adjusted in light of the } \\
\text { results of the external environment analysis of the } \\
\text { Union. }\end{array}$ & 10 \\
\hline & & $\begin{array}{l}\text { The evaluation process focuses on measuring } \\
\text { creativity, innovation and development among } \\
\text { Union members. }\end{array}$ & 11 \\
\hline & & $\begin{array}{l}\text { The calendar balances a measure of long-term and } \\
\text { short-term goal achievement. }\end{array}$ & 12 \\
\hline & & $\begin{array}{l}\text { The objectives of the courses and programs are } \\
\text { analyzed to ensure that they cover the general } \\
\text { objectives of the Union. }\end{array}$ & 13 \\
\hline & & $\begin{array}{l}\text { The Federation administration is keen to } \\
\text { communicate the results of the Union's } \\
\text { performance evaluation to its members and the } \\
\text { beneficiaries of its services. }\end{array}$ & 14 \\
\hline & & $\begin{array}{l}\text { Long-term plans are reviewed annually to ensure } \\
\text { suitability for changes. }\end{array}$ & 15 \\
\hline & & $\begin{array}{l}\text { The Federation carries out periodic surveys to } \\
\text { assess the extent of satisfaction of its members and } \\
\text { beneficiaries of its services. }\end{array}$ & 16 \\
\hline & & $\begin{array}{l}\text { The evaluation process covers all important } \\
\text { aspects of the Federation's performance and its } \\
\text { internal and external environment. }\end{array}$ & 17 \\
\hline
\end{tabular}

Annex (4)

Questionnaire paragraphs for the areas of strategic planning scale after the experts

\begin{tabular}{|c|l|l|l|l|l|c|}
\hline Star & Scarcely & Sometimes & frequently & Always & Paragraph & sequence \\
\hline & & & & $\begin{array}{l}\text { The message of the federation is in line } \\
\text { with its available capabilities. }\end{array}$ & 1 \\
\hline & & & $\begin{array}{l}\text { The Union publishes its message clearly } \\
\text { and in writing in its various branches } \\
\text { inside Iraq. }\end{array}$ & 2 \\
& & & & $\begin{array}{l}\text { The mission of the Union's strategic } \\
\text { planning is comprehensive and realistic. }\end{array}$ & 3 \\
\hline
\end{tabular}




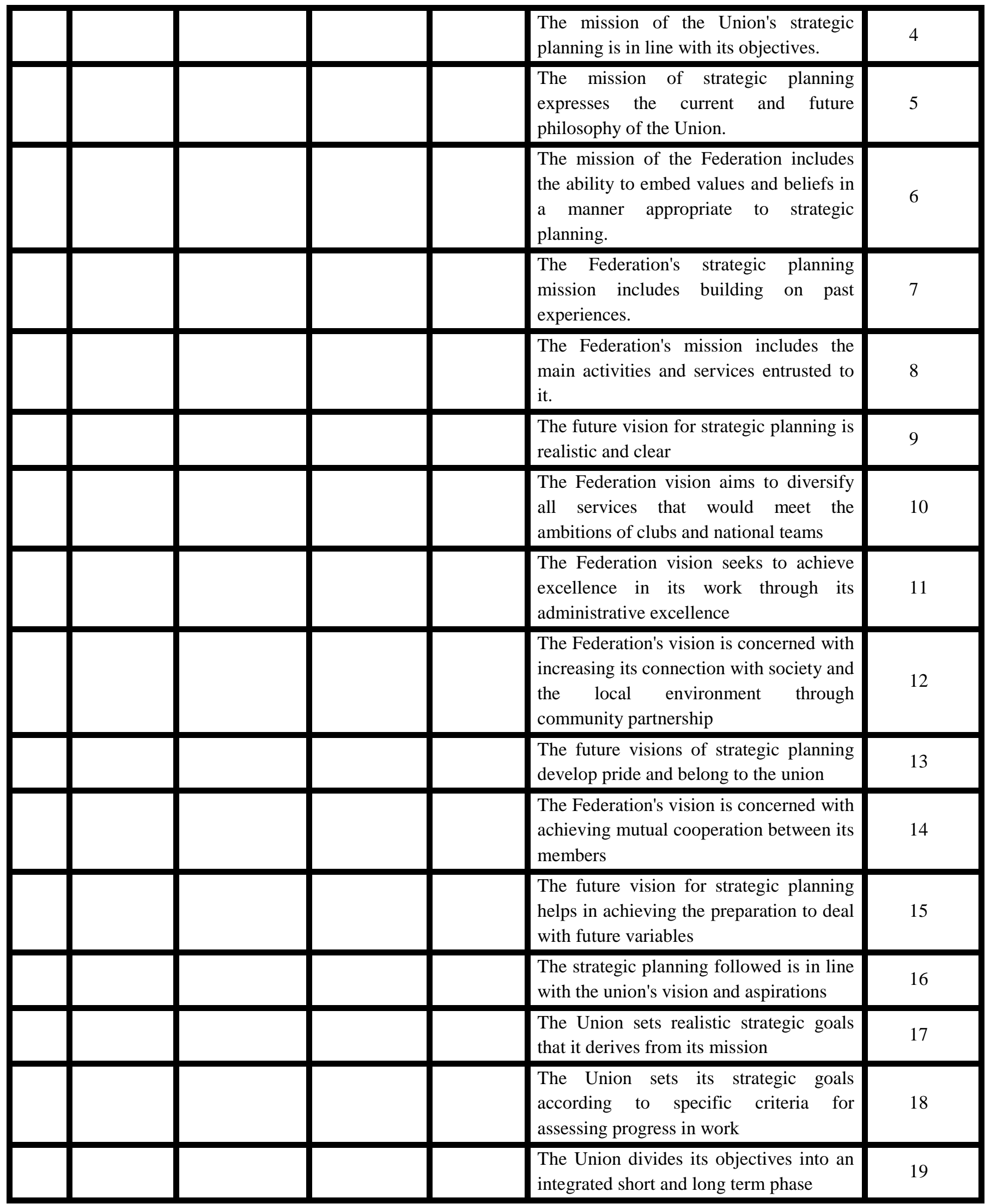




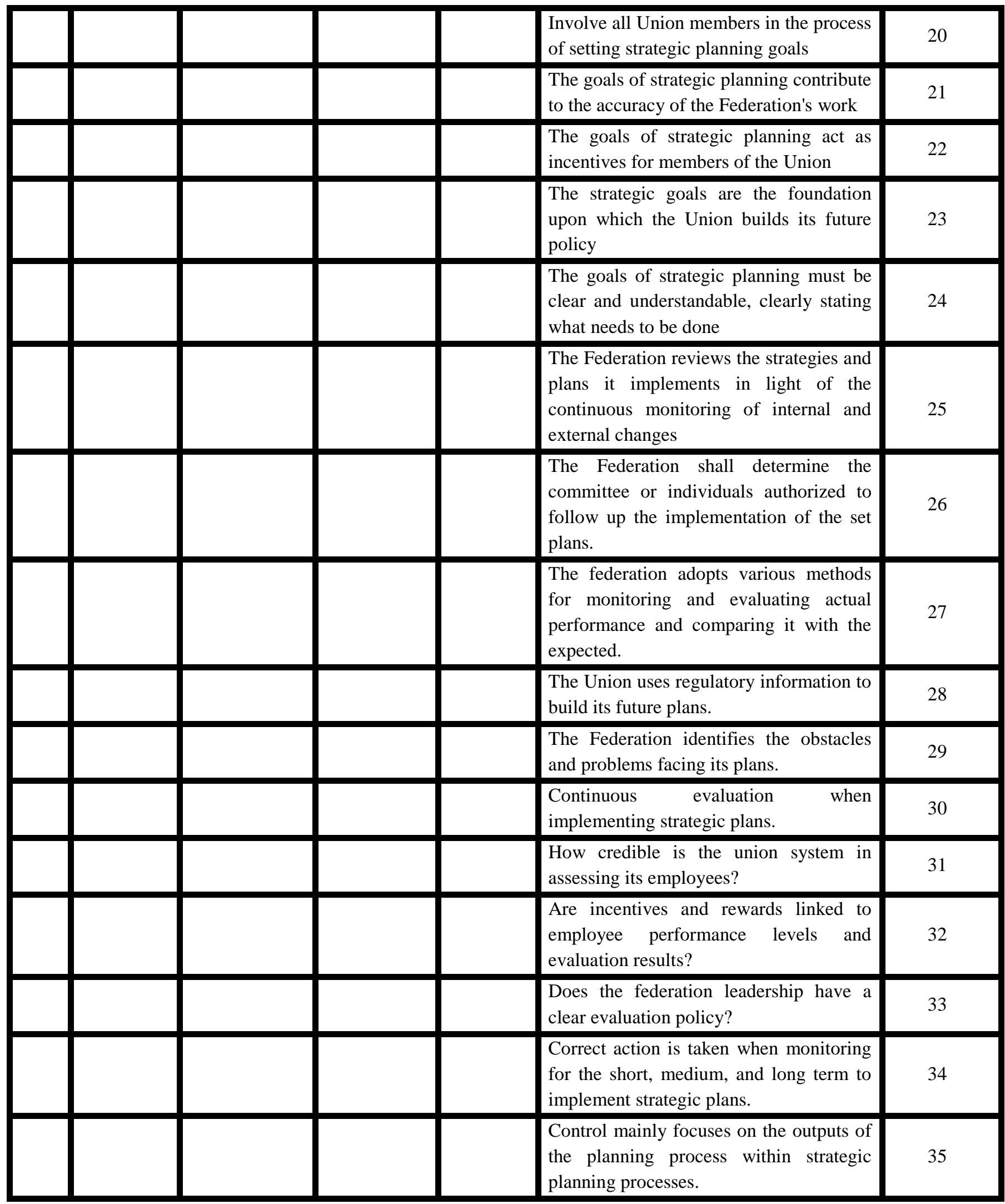




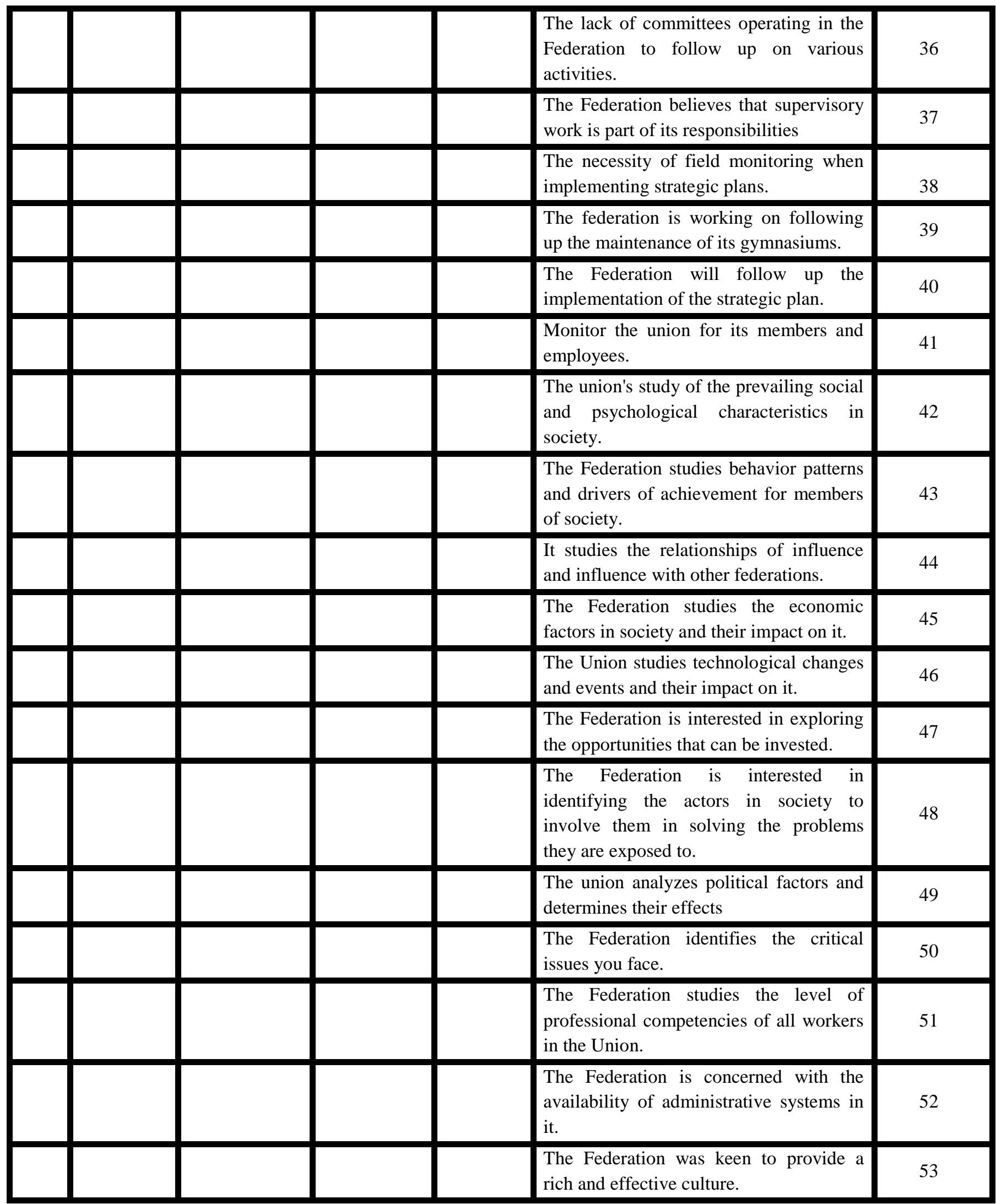




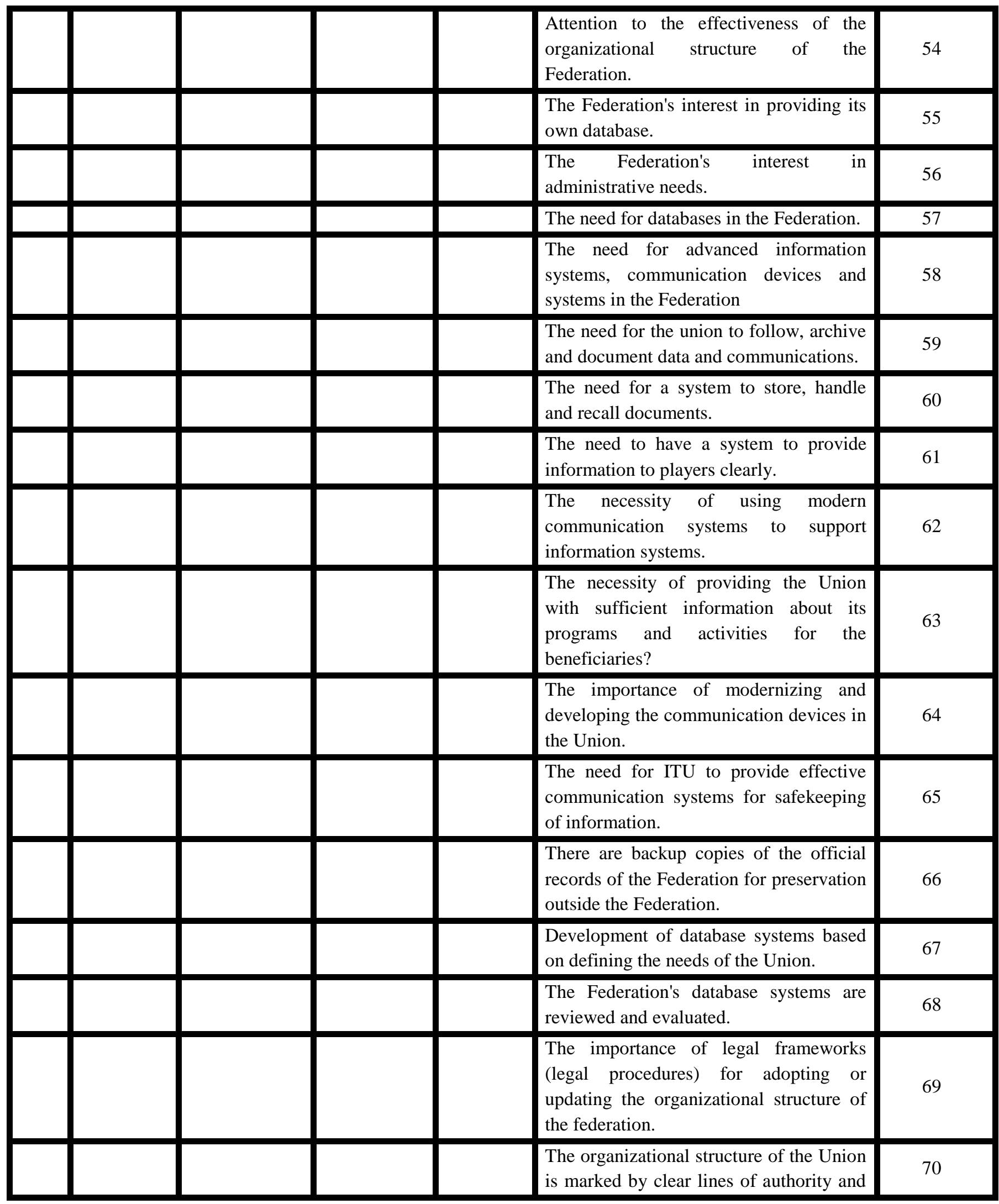




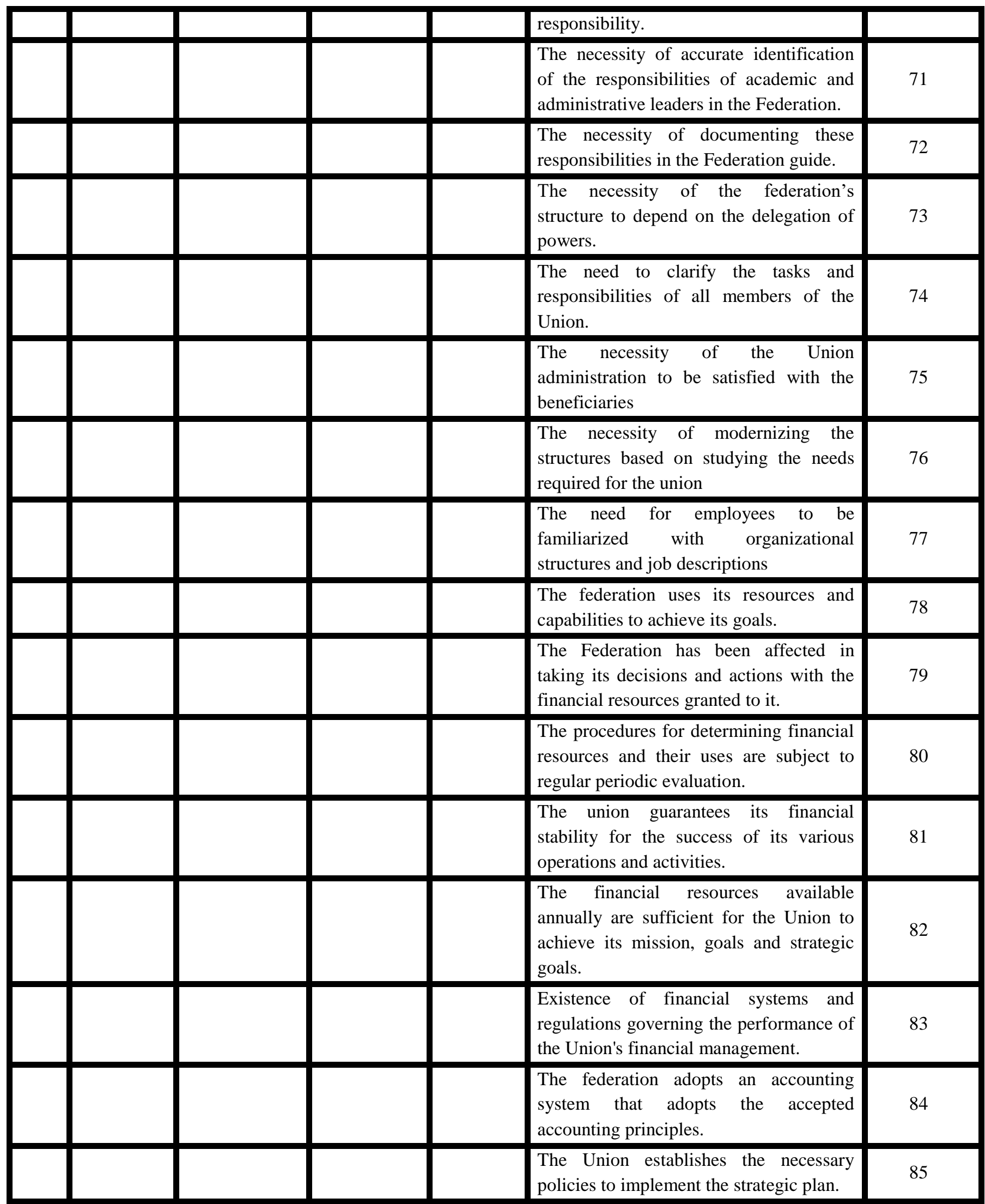




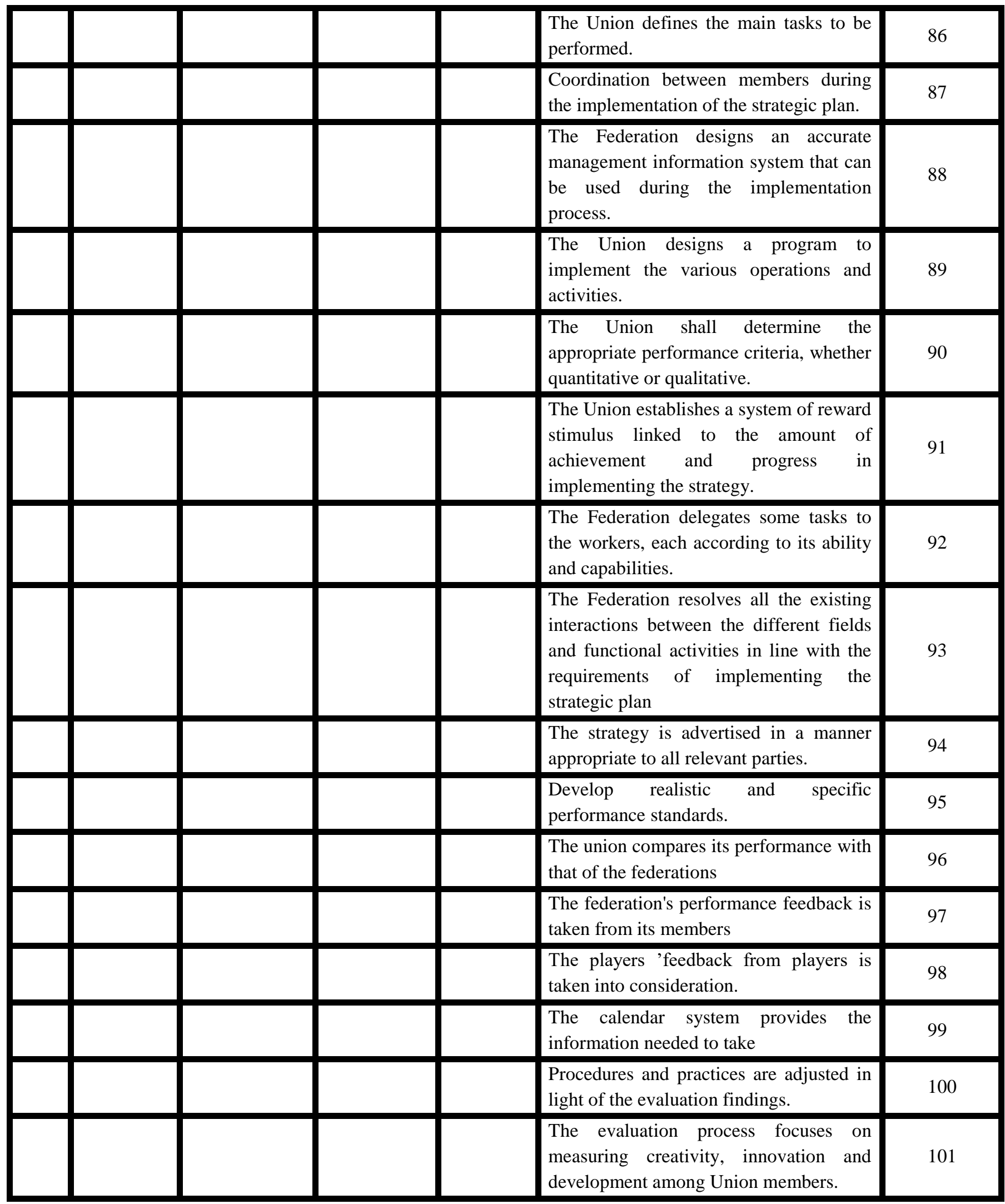




\begin{tabular}{|l|l|l|l|l|}
\hline & & & $\begin{array}{l}\text { The calendar balances a measure of long- } \\
\text { term and short-term goal achievement. }\end{array}$ & 102 \\
\hline & & & $\begin{array}{l}\text { The objectives of the courses and } \\
\text { programs are analyzed to ensure that they } \\
\text { cover the general objectives of the Union. }\end{array}$ & 103 \\
\hline
\end{tabular}

Annex (5)

The scale of strategic planning, in the final form

\begin{tabular}{|c|c|c|c|c|c|c|}
\hline Star & Scarcely & Sometimes & frequently & Always & Paragraph & sequence \\
\hline & & & & & $\begin{array}{l}\text { The message of the federation is in line } \\
\text { with its available capabilities. }\end{array}$ & 1 \\
\hline & & & & & $\begin{array}{l}\text { The Union publishes its message clearly } \\
\text { and in writing in its various branches } \\
\text { inside Iraq. }\end{array}$ & 2 \\
\hline & & & & & $\begin{array}{l}\text { The mission of the Union's strategic } \\
\text { planning is comprehensive and realistic. }\end{array}$ & 3 \\
\hline & & & & & $\begin{array}{l}\text { The mission of the Union's strategic } \\
\text { planning is in line with its objectives. }\end{array}$ & 4 \\
\hline & & & & & $\begin{array}{l}\text { The mission of strategic planning } \\
\text { expresses the current and future } \\
\text { philosophy of the Union. }\end{array}$ & 5 \\
\hline & & & & & $\begin{array}{l}\text { The mission of the Federation includes the } \\
\text { ability to embed values and beliefs in a } \\
\text { manner appropriate to strategic planning. }\end{array}$ & 6 \\
\hline & & & & & 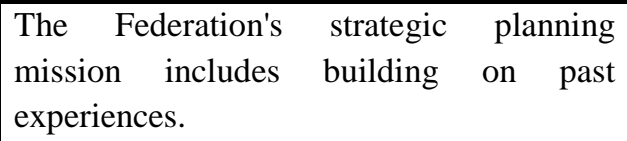 & 7 \\
\hline & & & & & $\begin{array}{l}\text { The Federation's mission includes the main } \\
\text { activities and services entrusted to it. }\end{array}$ & 8 \\
\hline & & & & & $\begin{array}{l}\text { The future vision for strategic planning is } \\
\text { realistic and clear }\end{array}$ & 9 \\
\hline & & & & & $\begin{array}{l}\text { The Federation vision aims to diversify all } \\
\text { services that would meet the ambitions of } \\
\text { clubs and national teams }\end{array}$ & 10 \\
\hline & & & & & $\begin{array}{l}\text { The Federation vision seeks to achieve } \\
\text { excellence in its work through its } \\
\text { administrative excellence }\end{array}$ & 11 \\
\hline & & & & & $\begin{array}{l}\text { The Federation's vision is concerned with } \\
\text { increasing its connection with society and } \\
\text { the local environment through community } \\
\text { partnership }\end{array}$ & 12 \\
\hline & & & & & $\begin{array}{l}\text { The future visions of strategic planning } \\
\text { develop pride and belong to the union }\end{array}$ & 13 \\
\hline & & & & & The Federation's vision is concerned with & 14 \\
\hline
\end{tabular}




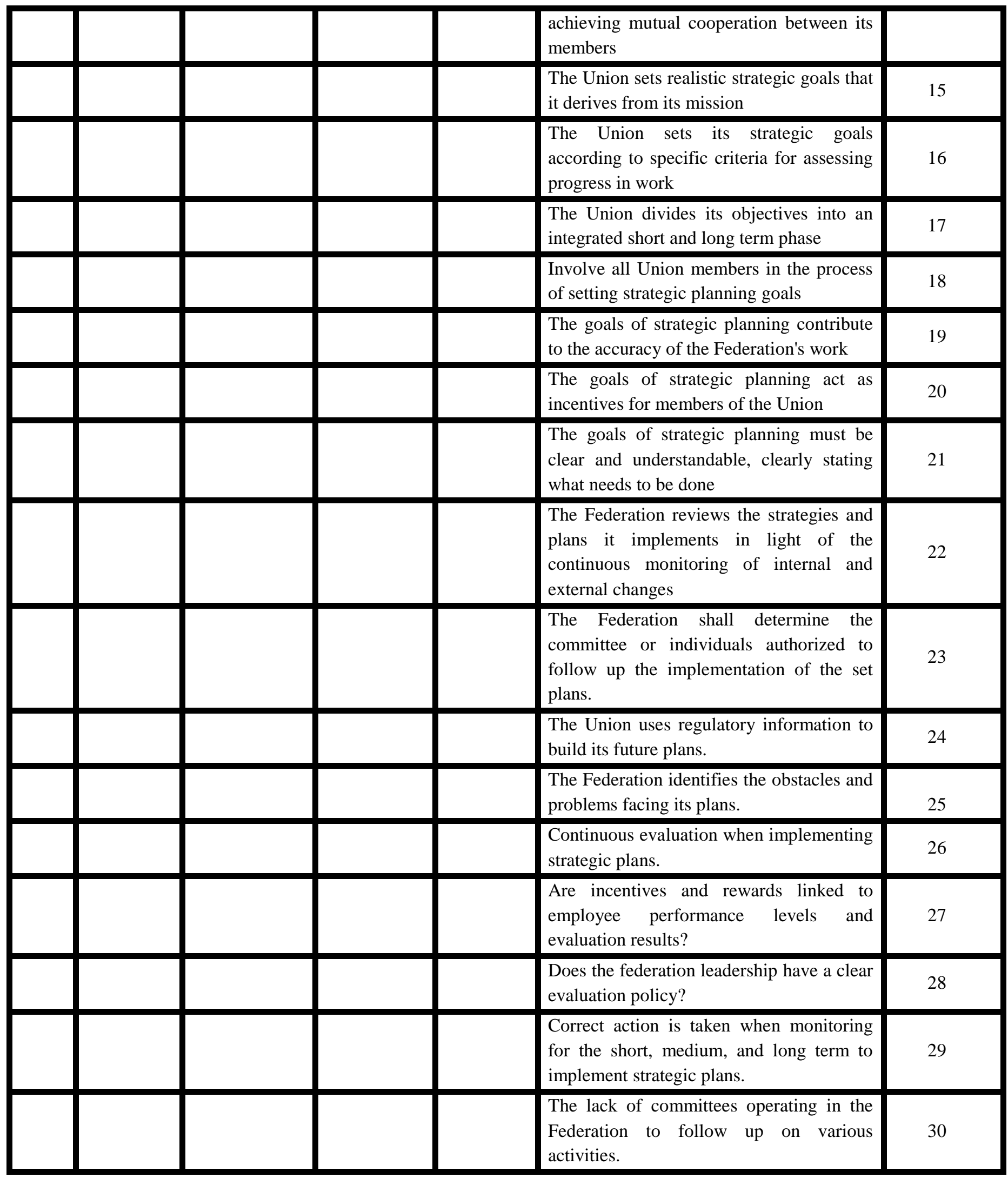




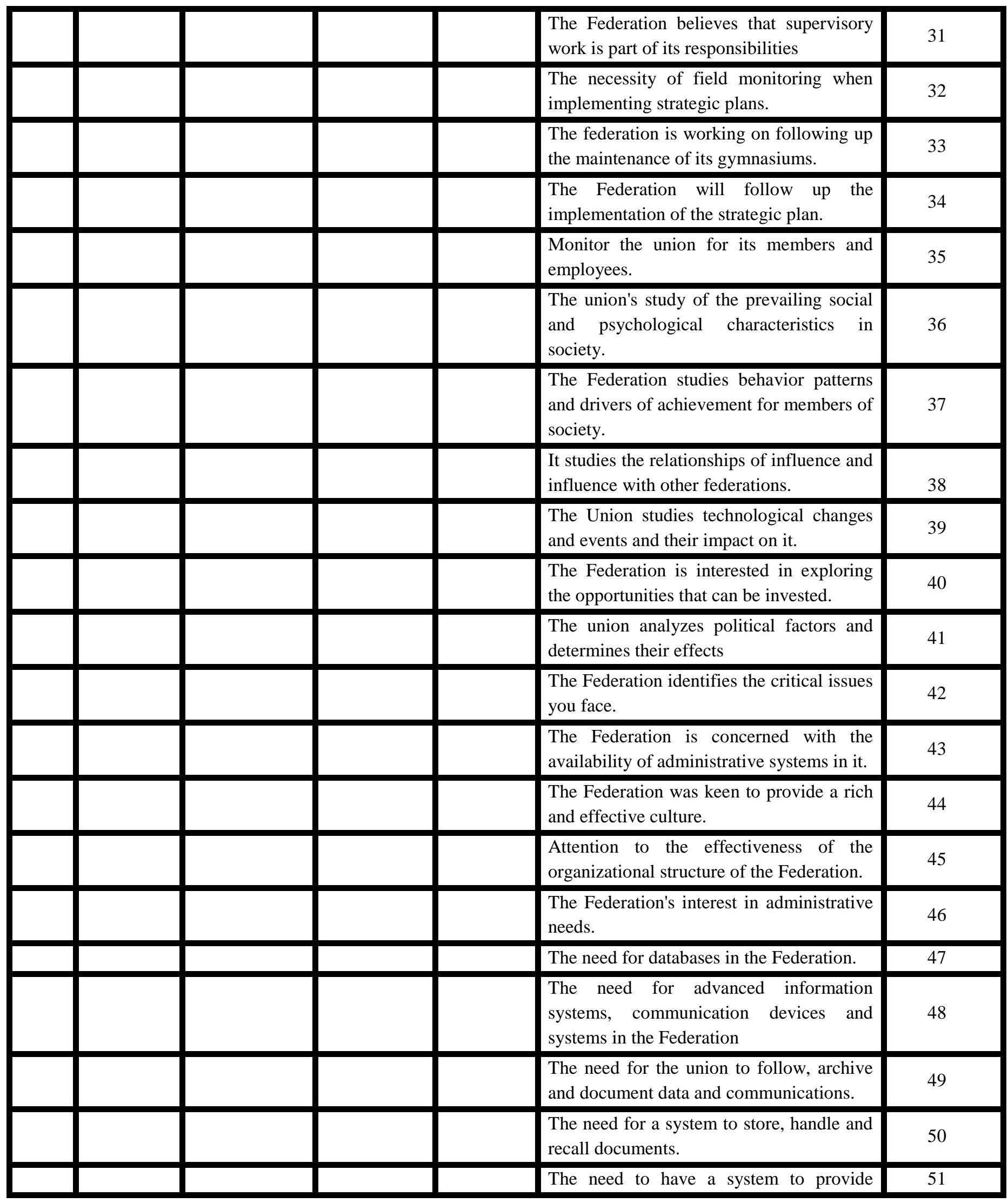




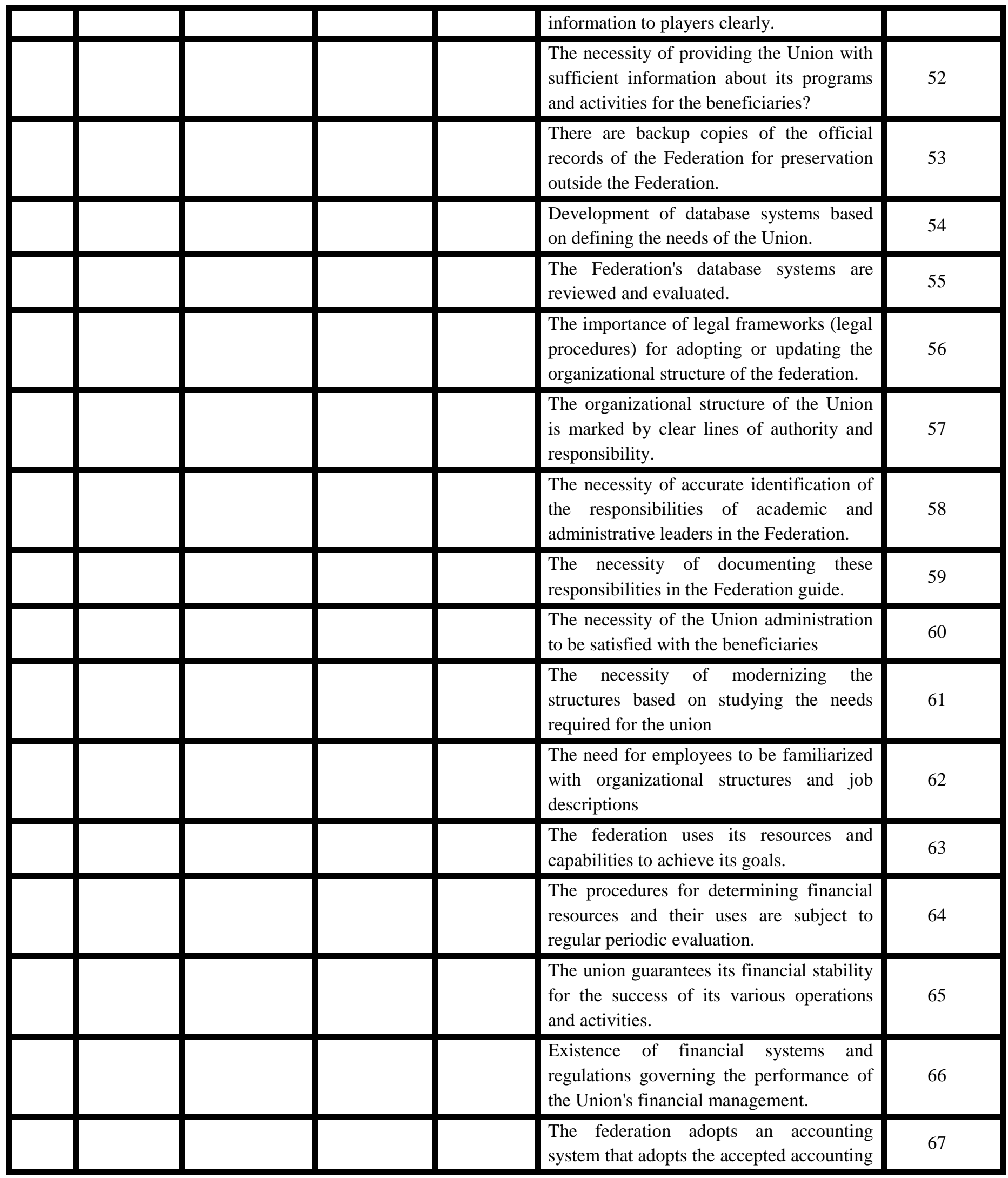




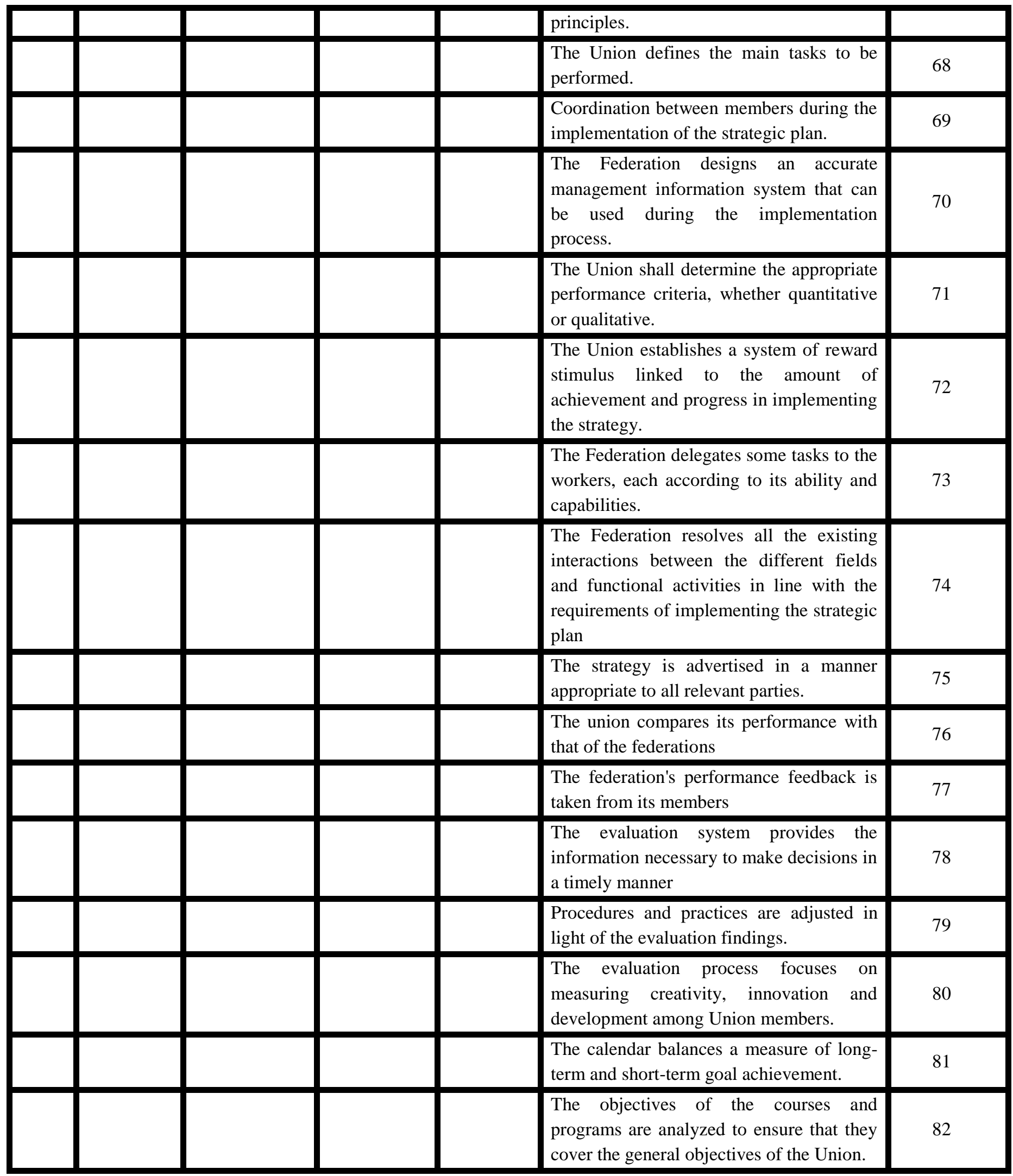

